Document downloaded from:

http://hdl.handle.net/10251/79936

This paper must be cited as:

Medina, JR.; Gómez-Martín, ME.; Corredor-Molguero, A.; Torres-Samper, R.; Miñana, J.; Fernández, E.; Menéndez, C.... (2011). Prototype Drop Tests of Cube and Cubipod Armor Units. Journal of Waterway, Port, Coastal, and Ocean Engineering. 137(2):54-63. doi:10.1061/(ASCE)WW.1943-5460.0000064.

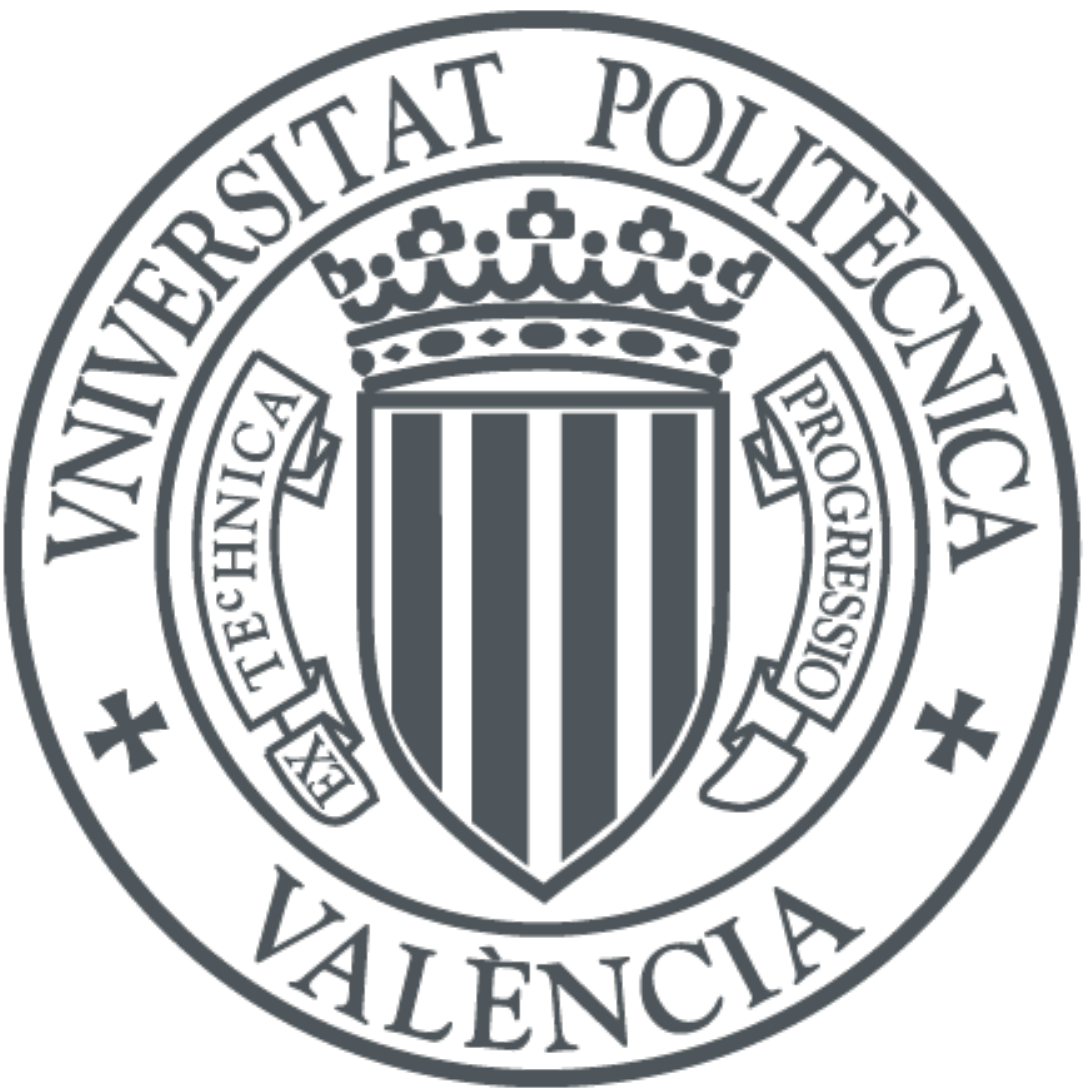

The final publication is available at

http://ascelibrary.org/doi/10.1061/\%28ASCE\%29WW.1943-5460.0000064

Copyright American Society of Civil Engineers

Additional Information 


\section{Prototype Drop Tests of Cube and Cubipod Armor Units}

Josep R. Medina, M.ASCE ${ }^{1}$; M. Esther Gómez-Martín²; Antonio Corredor ${ }^{3}$; Rafael Torres ${ }^{4}$; Juan V. Miñana ${ }^{5}$; Enrique Fernández ${ }^{6}$; Carlos F. Menéndez ${ }^{7}$; and Moisés Santos ${ }^{8}$

${ }^{1}$ Professor, Dept. of Transportation, ETSI Caminos, Universidad Politécnica de Valencia,

Camino de Vera s/n, 46022 Valencia, Spain (corresponding author). E-mail: jrmedina@upv.es.

${ }^{2}$ Assistant Professor, Dept. of Construction, Universidad de Alicante, San Vicent del Raspeig s/n, 03690 Alicante, Spain. E-mail: esther.gomez@ua.es.

${ }^{3}$ Technical Manager, SATO Construction Company (OHL Group), Paseo de la Castellana, 259 D, 28046 Madrid, Spain. E-mail: acorred@ohl.es.

${ }^{4}$ Director, SATO Construction Company (OHL Group), Paseo de la Castellana, 259 D,

28046 Madrid, Spain. E-mails: rtorres@ohl.es.

${ }^{5}$ Project Manager, SATO Construction Company (OHL Group), Paseo de la Castellana, 259

D, 28046 Madrid, Spain. E-mails: jvicmina@ohl.es.

${ }^{6}$ Project Engineer, SATO Construction Company (OHL Group), Paseo de la Castellana, 259

D, 28046 Madrid, Spain. E-mails: efernand@ohl.es.

${ }^{7}$ Site Manager, SATO Construction Company (OHL Group), Paseo de la Castellana, 259 D, 28046 Madrid, Spain. E-mails: cmenende@ohl.es.

${ }^{8}$ Commercial Manager, SATO Construction Company (OHL Group), Paseo de la Castellana, 259 D, 28046 Madrid, Spain. E-mails: mosantos@ohl.es. 


\begin{abstract}
In this paper, an experimental methodology is described to assess the structural strength of unreinforced concrete armor units (CAUs). The methodology is applied to measure the structural integrity under impact loads of the new Cubipod CAU compared to the conventional cube CAU. The casting systems and clamps are described to manufacture and handle the 15-tonne conventional cubic block and 16-tonne Cubipod prototypes used for the drop tests. Two separate reinforced-concrete platforms were used for overturning and free fall tests, respectively; Cubipods withstand drops more than 50\% higher than conventional cubes of similar size and concrete strength. Two extreme free fall tests, confirmed the structural robustness of Cubipod armor units. Manufacturing cycletime as well as storage and handling procedures are similar for both Cubipods and conventional cubic blocks.
\end{abstract}

Key words: Breakwaters, Armor unit, Cubipod, Prototype test, Drop test, Concrete block. 


\section{Introduction}

The armor layer of rubble-mound breakwaters is considered the most important part of the breakwater; armor erosion due to wave attack is the critic failure mode for most rubblemound breakwaters and the main problem to be solved in the design process. The higher the waves attacking the breakwater, the larger the stones for the armor layer; if local quarries can not provide the volume of large enough stones for the armor, usually CAUs have to be manufactured for the armor layer. During the $19^{\text {th }}$ century, when rubble-mound breakwaters were constructed in deeper waters and in stronger wave climates, unreinforced concrete cubic and parallelepiped blocks were used worldwide as CAUs.

The invention of the Tetrapod in 1950 and the publication of Hudson's formula focused the attention of the engineering community on the stability coefficient $\left(K_{D}\right)$ associated with each armor unit geometry; the larger the $\mathrm{K}_{\mathrm{D}}$, the smaller the armor unit weight to resist a given design wave. Hudson's formula, based on the formula given by Iribarren (1938), was proposed for regular waves, and SPM (1975) popularized the formula for irregular waves using the equivalence $\mathrm{H}=\mathrm{H}_{\mathrm{s}}$. According to Hudson's formula, the weight of the CAU for Initiation of Damage (IDa) was proportional to the inverse of $\mathrm{K}_{\mathrm{D}}$; therefore, a higher $\mathrm{K}_{\mathrm{D}}$ reduced the CAU weight to be handled, the volume of concrete required for armor construction as well as the size and volume of stones in the under-layer. Therefore, in 1950 technology began a race to design CAUs units with higher $\mathrm{K}_{\mathrm{D}}$, in order to reduce breakwater construction costs. 
The Dolos, invented in 1963, epitomized a successful CAU characterized by its very high $\mathrm{K}_{\mathrm{D}}$; numerous Dolos-armored breakwaters were constructed worldwide; however, the catastrophic failure of the 2-km, 42-tonne Dolos breakwater in the Port of Sines (Portugal) in 1978 forced the engineering community to address the deficiencies related to the CAU structural strength (see Dupray and Roberts, 2009). It was observed that many 42-tonne Dolos CAUs were broken in parts during the Port of Sines breakwater failure. Stresses due to static loads on CAUs increase linearly to the CAU size; therefore, Dolosse and other slender CAUs may resist impacts and static interlocking forces in small scale experiments and when prototypes are small, but they break apart very easily when prototypes are large.

After the Port of Sines breakwater failure, it was evident that not only hydraulic stability but also structural integrity should be taken into consideration for CAU selection. On the one hand, conventional, randomly-placed, double-layer armors, constructed with massive CAUs like Antifer cubes and conventional cubic blocks, were favored for breakwaters under severe design wave climates. On the other hand, a variety of bulky CAUs were designed in attempts to balance structural strength and hydraulic stability, to construct single-layer armors and also armors with special placement patterns (see Dupray and Roberts, 2009). Therefore, it is common to classify CAUs according to their qualitative robustness (slender, bulky and massive), their placement method (random or special) and the armor thickness (single, double or multi-layer). Due to the fact that mound breakwaters are designed based on the hydraulic stability results of Froude's similarity small-scale models, CAU structural integrity must be guaranteed at the prototype scale; this is one reason which may explain why modern mound breakwaters under the severest wave climates in the world are armored with massive, unreinforced CAUs or slender, reinforced CAUs. For instance, Burcharth et al. (2002) described the 150-tonne unreinforced concrete cube breakwater at La Coruña (Spain) while 
Hanzawa et al. (2006) reported on the use of fully reinforced Dolosse up to 80 tonne in Japan. Not only must CAU integrity be guaranteed, but real breakwaters should have a porosity and CAU placement similar to those of the small-scale models used in breakwater design.

Most slender and bulky CAUs tend to generate strong interlocking forces; in these cases, small-scale hydraulic stability tests show high stability coefficients, though armor unit integrity and placement must be assured at prototype scale. Muttray et al. (2005) described recent cases of damage to breakwaters caused by breakage of bulky CAUs and improper placement. Additionally, interlocking forces increase armor resistance to IDa but reduce the safety margin to Initiation of Destruction (IDe), which may occur very close to IDa; on the contrary, conventional double-layer armors of randomly-placed quarrystones or massive CAUs ensure an ample safety margin from IDa to IDe. Although conventional cubic blocks are robust CAUs and have logistic advantages for construction when compared to slender or bulky CAUs, they do have drawbacks like low $\mathrm{K}_{\mathrm{D}}$, low friction with the under-layer and a tendency to face-to-face fitting which significantly reduces porosity over time. GómezMartín and Medina $(2006,2007)$ demonstrated that both CAU extraction and Heterogeneous Packing $(\mathrm{HeP})$ cause armor damage, reducing CAU packing density around the mean water level. The new Cubipod CAU is actually a conventional cube with protrusions on each of its faces. These protrusions prevent face-to-face fitting and $\mathrm{HeP}$, increase friction with the under-layer and increase $K_{D}$. Gómez-Martín and Medina (2008) have found that double-layer Cubipod armors feature much higher hydraulic stability than cube armors. Cubipods can also be used to construct single-layer armors with random placement; if a Cubipod unit is extracted from the armor layer, neighboring units move generating a self-arrangement of CAUs. 
In this paper, the problem of CAU integrity is first analyzed. The experimental design of prototype drop tests for conventional cubes and Cubipods as well as the results prototype overturning, free-fall and extreme free-fall tests are described in detail. Finally, the conclusions are drawn regarding the design and construction of armor layers and the experimental design of prototype armor unit drop tests.

\section{Armor Unit Integrity}

At prototype scale, unreinforced CAUs are far cheaper than reinforced ones, but CAU integrity must be guaranteed. Unreinforced CAU integrity depends on the concrete specifications and the variety of structural loads. According to Burcharth et al. (2000) and Tedesco et al. (2003), loads on armor units can be classified as (1) static, hydrodynamic or dynamic-pulsating, or (2) impact or dynamic-impact. Additionally, biological, chemical, thermal and other environmental agents may damage CAUs. Static loads are caused by selfweight, breakwater settlement as well as CAU prestressing from both interlocking and the force between CAUs. Hydrodynamic loads are caused by waves attacking the structure (see McDougal et al., 1988) which may also generate the rocking of units and subsequent impact loads. Finally, possibilities for impact loads on CAUs are numerous such as collisions between CAUs when rocking or rolling, impact of pieces of broken CAUs, as well as impacts during transport, handling and placement.

Although CAU integrity is a qualitative concept which is easily understood in terms of the mechanical strength of the unit, yet quite difficult to define in detail and quantify. Not only are the possibilities for loads on CAUs numerous but they also are inter-related and interact to amplify the damage. At present, the variables and degrees of freedom affecting CAU 
integrity are so numerous that it is impossible to quantify the entire process for complexshape slender CAUs or even much more basic massive CAUs such as conventional cubes and Cubipods. Therefore, it is necessary to simplify the assessment of CAU integrity by reducing the variables and degrees of freedom to an acceptable number.

From the numerous structural load types influencing CAU integrity, only a few can be considered for testing specific loading scenarios. In order to develop an appropriate methodology to assess the structural strength of the new Cubipod CAU, to guarantee structural integrity as desired, it is convenient to review the methodologies used for other CAUs such as cube, Dolos, Tetrapod, Accropode, A-Jack, Core-Loc and Xbloc. The best methodology will be determined in terms of CAU shape, available testing facilities and resources and financial support.

Lillevang et al. (1976) used the 3D photoelastic stress analysis to study the breakage of Dolosse at 15 locations worldwide before the Port of Sines breakwater failure; they proposed analyzing Dolos, in a number of static loading tests to make estimations of large-size Dolos stress concentration. Dimensional analysis in addition to specifically-designed prototype drop tests and impact tests were proposed by Burcharth (1981) in an attempt to rationalize the relationship between CAU size and structural integrity; 1.5-tonne and 5.4-tonne unreinforced as well as reinforced Dolos were used in the drop tests. As a rule of thumb, Burcharth and Brejnegaard-Nielsen (1986) pointed out that the stress level in CAUs due to static and hydrodynamic loads increases linearly with CAU size, while impacts generate stress levels proportional to the squared root of the CAU size. In a parallel study, Nishigori et al. (1989) experimentally analyzed the similarity laws of impact for Tetrapod CAUs. Burcharth et al. (1991) discussed direct and indirect methods to assess CAU integrity by raising theoretical 
and practical questions about the use of indirect methods and proposing direct methods based on the use of strain gauges in small-scale and large-scale Dolos. These authors also highlighted the stochastic behavior of CAU tensile stress and the increase in CAU stresses due to armor compaction and settlement during lifetime. Burcharth et al. (2000) examined scaling laws for a variety of static, hydrodynamic and impact loads confirming the earlier rule of thumb given by Burcharth and Brejnegaard-Nielsen (1986) and then proposed empirical formulae to estimate the number of broken Dolosse and Tetrapods in prototype situations.

The 3D Finite Element Method (FEM) has been used extensively to estimate the static load scenarios representing prototype handling and storage. Melby and Turk (1995) compared the results of FEM models for Tribar, Dolos, Accropode and Core-Loc units under a variety of static loading conditions while Hakenberg et al. (2004) compared the results obtained from FEM models of Accropode, Core-Loc and Xblocs. The dynamic FEM models were reported by Tedesco et al. (1988) for Dolosse, by Tedesco et al. (2003) for A-Jacks and by Hakenberg et al. (2004) for Xbloc. However, both static and dynamic FEM models have serious limitations to represent real conditions; on the one hand, static FEM models are used for a limited number of man-prescribed static loads, on the other hand, the results of dynamic FEM models are very sensitive to theoretical materials properties and platform stiffness as well as the idealistic impact conditions. Recently, Latham and Xiang (2009) proposed the use of combined Finite-Discrete Element Method (FEMDEM) with more realistic elastic-plastic constitutive, contact friction and other models to create suitable simulators because elastic idealized models clearly overestimate CAUs internal maximum tensile stress caused by impacts. 
Prototype 36-tonne Dolosse CAUs were internally instrumented during the construction of the Crescent City jetty (California) to measure bending moments and torque; Howell (1998) described the instrumented section and measurements from January 1987 to May 1988. Indeed, numerous papers in the literature about numerical and physical experiments of Dolos CAUs are related to the Crescent City prototype experiment. Additionally, small-scale instrumented CAUs have been used to assess the static and hydrodynamic loads on CAUs. Nishigori et al. (1986) tested surface strains on $50 \mathrm{~kg}$ Tetrapods to assess the behavior of Tetrapods under wave attack. Scott et al. (1990) analyzed the static and wave-induced forces on small-scale $0.5 \mathrm{~kg}$ Dolos CAUs using internal load cells to measure bending moments and torque. Burcharth et al. (1991) experimented with 200-kg and 0.2-Kg load-cell instrumented Dolosse to analyze static and wave generated stresses and scale effects. Nevertheless, Turk and Melby (1994) raised doubts about the reliability of small-scale instrumented CAUs when estimating maximum stresses in Dolosse, and proposed using 26-kg Dolosse models instrumented with surface-mounted strain gauges to measure Dolos CAU stresses.

Small-scale drop tests and numerical models are not very reliable when assessing CAU structural strength in prototype conditions; therefore, several prototype scale dynamic tests have been used over the past three decades to assess the structural strength of CAUs. Burcharth (1981) and Silva (1983) tested 1.5-tonne and 5.4-tonne Dolosse, and 1-tonne to 27tonne cubic blocks, respectively. Nishigori et al. (1989) tested 2 to 4-tonne Tetrapods; Turk and Melby (1998) compared drop tests of 9-tonne Core-Locs and 11-tonne Dolosse CAUs. Later, Muttray et al. (2004) described the drop test results corresponding to 9-tonne Xblocs, 9-tonne Core-Locs and 15-tonne Accropodes. In this paper, recent drop tests using 15-tonne cubic blocks and 16-tonne Cubipods, described by Medina et al. (2009), are analyzed in detail. 


\section{Prototype Drop Tests Design}

Prototype drop tests are expensive and heavily dependent on both available local facilities and geometric characteristics of the specific CAU to be tested; thus, few CAU specimens are ever tested to breakage. The prototype drop tests reported in the literature have distinct experimental designs, adapted to the CAU geometry and available local facilities. Burcharth (1981) designed specific hammer drop tests and pendulum tests for Dolos on a speciallydesigned $9.5 \mathrm{~m}^{3}$ reinforced concrete base; Silva (1983) used a railway and supporting cars to test up to 27-tonne cubic blocks forcing face-to-face impacts; Nishigori et al. (1989) described anvil drop tests of 4-tonne Tetrapods on a $30 \mathrm{~m}^{3}$ concrete slab; Turk and Melby (1998) reported anvil, hammer and tipping drop tests of 9-tonne Core-Locs and 11-tonne Dolosse CAUs on a $12 \mathrm{~m}^{3}$ concrete base, and finally Hakenberg et al. (2004) carried out free fall and several overturning tests comparable to anvil, hammer and tipping drop tests with 9tonne Xblocs on a $38 \mathrm{~m}^{3}$ reinforced-concrete base covered with a 30-mm steel plate.

To assess the structural strength of the cube and Cubipod CAUs, both the available local facilities and previous prototype drop tests methods were taken into consideration. On the one hand, the block yard used in the extension of the new breakwater at the Port of Alicante (Spain) was available along with its 63/25-tonne gantry crane which was able to elevate prototypes up to $9.5 \mathrm{~m}$ above the ground. On the other hand, Cubipod is a massive CAU and should be compared to other massive CAU such as the conventional cubic block. A prototype drop test program was designed for cube and Cubipod unreinforced CAUs having similar CAU size, handling, storage and concrete characteristics. The drop test maneuvers were designed to resemble those described by Muttray et al. (2004) for bulky armor units, but adapted to the higher structural strength and simpler geometry of cube and Cubipod CAUs. 


\section{Cubipod and conventional cubic block prototypes}

According to Burcharth et al. (1991), as a rule of thumb, concrete stresses in CAUs due to non-impact loads increase linearly with the unit size, while impact-induced stresses increase with the square root of the unit size. Taking into consideration the increase in concrete stress according to the unit size, and the higher mechanical strength of massive CAUs, 16-tonne $\left(7.1 \mathrm{~m}^{3}\right)$ Cubipod prototypes were considered for the prototype drop tests because they are larger than any drop tested bulky CAU reported in the literature and the armor unit weight is adequate for large breakwaters along the Spanish Mediterranean coast, corresponding to 1/50 scale when compared to the models used in the Cubipod hydraulic stability tests described by Gómez-Martín and Medina (2008). There were several 15-tonne molds already available for conventional cubic blocks in the Port of Alicante (Spain); thus, this study compared conventional 15-tonne cubes $\left(6.5 \mathrm{~m}^{3}\right)$ and 16-tonne Cubipods $\left(7.1 \mathrm{~m}^{3}\right)$ using the same concrete source and similar vibration system.

One important logistic advantage of the conventional cubic block versus other CAUs is the vertical casting, a mold which may be lifted six hours after pouring the concrete. To obtain this logistic advantage, SATO technicians designed and developed a vertical casting system for Cubipod. This system was used to manufacture the $7.1 \mathrm{~m}^{3}$ Cubipod CAUs for the prototype drop tests, and it features a base and also an upper part which can be lifted six hours after pouring the concrete in the mold and vibration. Figs. 1a and $1 \mathrm{~b}$ show pictures of the Cubipod and cube casting systems used for prototype manufacture. In order to facilitate the lifting maneuver of the upper part of the molds, when concrete has reached only a low strength, both conventional cube and Cubipod molds have a slight conic form to avoid vertical planes (see Corredor et al, 2008). The concrete poured into the molds correspond to 
the typical concrete used to manufacture cube CAUs in Spain: HA-30/B/25/IIIa+Qb with 350 $\mathrm{kg} / \mathrm{m}^{3}$ of cement CEM I $42.5 \mathrm{R}$, a 0.5 water/cement ratio and a $25 \mathrm{~mm}$ maximum aggregate size. The average and Coefficient of Variation $(\mathrm{CV})$ of the compressive strength of normalized probes, which were broken at 7 and 28 days, were 52.5 and $63.5 \mathrm{~N} / \mathrm{mm}^{2}(\mathrm{CV}=$ $8.3 \%$ and $8.2 \%)$ for cubes and 48.7 and $58.7 \mathrm{~N} / \mathrm{mm}^{2}(\mathrm{CV}=11.3 \%$ y $12.0 \%)$ for Cubipods, respectively. All cube and Cubipod prototypes were used for drop tests at least one month after produced and piled in the stocking area.

\section{[Insert Figs. 1a and $1 b$ here]}

\section{Prototype drop tests}

There are several sources of static and dynamic loads on armor units in breakwaters (see Burcharth et al., 2000). Overturning and free fall tests are designed to emulate the scenarios of collisions between CAUs when rocking or rolling as well as those of CAU collisions during handling, transport and placing on the armor layer. Overturning drop tests are those in which a prototype has multiple low energetic impacts on a stiff base, while free fall tests are those in which a prototype is dropped on a relatively stiff base. In this study, a wheeled excavator was used to force the cube and Cubipod overturning movements and a 65/25-tonne gantry crane was used to handle and drop the prototypes during the free fall tests. Additionally, to efficiently handle prototypes within the test area, conventional 20-tonne single clamp was used for the 15 tonne cubes, and adapted 2x20-tonne double clamp was used for the 16-tonne Cubipods.

Muttray et al. (2004) compared the methodology used in prototype drop tests carried out from 1984 to 2004 for three different bulky CAUs. The most recent systematic CAU prototype drop tests is described by Hakenberg et al. (2004) including overturning and free fall tests of Xbloc CAU prototypes on a single base consisting of a $10.0 \times 7.5 \times 0.5 \mathrm{~m}$ reinforced-concrete platform built on compacted sandy subsoil and covered with $30-\mathrm{mm}$ thick steel plates. In this study, to 
obtain data which might be comparable with those described in the literature, two different reinforced-concrete platforms, constructed on a highly compacted sandy soil in the Port of Alicante's block yard, were used for overturning and free fall tests, respectively. Overturning tests were expected to generate numerous low energetic impacts but they require a larger space for the wheeled excavator maneuvers; thus, the overturning base was a $10.0 \times 7.5 \times 0.9 \mathrm{~m}$ reinforced-concrete platform. Free fall tests were expected to generate high energetic impacts, but they require a relatively small space given the high precision of the gantry crane and the clamps used for handling and releasing prototypes; thus, the free fall platform was a $5.0 \times 5.0 \times 1.15 \mathrm{~m}$ reinforced-concrete platform, covered with a $20-\mathrm{mm}$ steel plate to avoid punching. In addition to constructing the two reinforced concrete platforms, it was necessary to carry out a specific prototype drop test safety project, including a protecting berm and a safety perimeter to prevent accidents during handling or injuries from the projection of broken parts of the dropped prototypes.

\section{Overturning tests}

Each specific CAU has a given set of possible overturning maneuvers, which depend on its geometric characteristics and possible stable positions on the ground. The cube has only one stable position on the ground and can only be overturned on one of its four bottom edges maintaining a vertical symmetry plane perpendicular to the edge. The Cubipod has two stable positions and can be overturned in two different ways. More complex slender and bulky CAUs have many more possible overturning maneuvers. In this experiment, two cube prototypes were used in partial and complete overturning tests and four Cubipod prototypes were used in frontal and diagonal overturning tests.

A wheeled excavator tipped the cube for overturning tests; partial overturning was tested if the 
angle between the platform and the cube bottom face was $15 \%$ just before releasing it, while complete overturning was tested if the angle reached $45^{\circ}$ before the cube falls on to the platform. Figs. $2 \mathrm{a}$ and $2 \mathrm{~b}$ show schemes of the partial and complete cube overturning tests, the force applied and suppressed by the wheeled excavator as well as the movement of the prototype center of gravity when released. The damage caused by an impact is expected to be proportional to the impact energy, which tends to increase linearly with the drop height, defined as the vertical distance between the centers of gravity of the prototype just before releasing it and when it first hits the platform. The 15 -tonne $\left(6.5 \mathrm{~m}^{3}\right)$ cube prototypes had a nominal diameter $\operatorname{Dn}[\mathrm{m}]=1.86$; the drop heights for partial and complete overturning tests were $\mathrm{h}[\mathrm{m}]=0.20$ and $\mathrm{h}[\mathrm{m}]=0.39$, respectively. One cube prototype was used for partial overturning test and another for complete overturning test; the two cube prototypes were weighed after 8, 16 and 24 overturning impacts to measure the Relative Loss of Mass (RLM).

\section{[Insert Fig.2 here]}

The overturning tests for Cubipod prototypes were similar to those designed for cubes. The wheeled excavator pushed the Cubipod for overturning; frontal overturning was tested if the force was in the vertical symmetry plane, while diagonal overturning was tested if the force was asymmetric causing the prototype to move laterally. In the case of Cubipod overturning tests, every time the prototype was pushed, it usually rebounded twice on the overturning platform. The 16-tonne $\left(7.1 \mathrm{~m}^{3}\right)$ Cubipod prototypes had a nominal diameter $\operatorname{Dn}[\mathrm{m}]=1.92$; the drop height for both frontal and diagonal overturning tests was $\mathrm{h}[\mathrm{m}]=0.13$. The four prototypes were weighed after 20, 40 and 60 overturning pushes to measure RLM.

\section{Free fall tests}

The CAU damage in prototype drop test depends on the prototype size, concrete strength, drop test type, drop height, platform stiffness and accumulation of damage inside the prototype. 
Because prototype size and concrete strength were similar for cube and Cubipod prototypes, similar free fall tests were designed for cubes and Cubipods. Cubipod and cube prototypes were dropped alternatively on the free fall platform to guarantee similar platform stiffness although stiffness may decrease over time due to many accumulated minor damages during the free fall tests. The RLM was the quantitative damage variable considered in this study and the drop height (h) and the number of drops (n) were the fundamental independent variables for the RLM. The sound of the impacts, as well as the small cracks in prototypes and platforms, observed visually, were valuable secondary qualitative information, which proved valuable to roughly estimate the result of the following prototype drop test.

Three different free fall tests were designed: (1) "Anvil Drop" (AD), in which the prototype is dropped with one of its faces parallel to the platform; (2) "Edge Drop" (ED), in which the prototype is rotated $45^{\circ}$ and dropped with only one of its edges parallel to the platform, and (3) "Random Drop" (RD), in which the test prototype hang from the gantry crane but touched the top of a cube prototype placed on the ground, and then the test unit was released for an unpredictable fall onto the free fall platform. Figs. $3 \mathrm{a}$ and $3 \mathrm{~b}$ show cube and Cubipod prototype positions just before release during the $\mathrm{AD}$ test; drop height $(\mathrm{h})$ and fall movement are represented by thick arrows. Similarly, Figs. $4 \mathrm{a}$ and $4 \mathrm{~b}$ show prototype positions for ED tests while Figs. 5a and $5 \mathrm{~b}$ illustrated prototype positions for RD tests. The criteria to conduct the free fall tests were: (1) to increase the drop height progressively, (2) to drop each prototype a maximum of six times from a given drop height, and (3) to drop alternatively Cubipod and cube prototypes on the free fall platform.

\section{[Insert Figs. 3 to 5 here]}




\section{Overturning and free fall test results}

Cube and Cubipod prototypes were manufactured in January 2008 and stacked in the block yard testing area. The prototype drop tests were scheduled in the Port of Alicante's block yard from March 3-7, 2008. A well-trained team with experience in handling blocks collaborated in the experiment.

In addition to the 65/25-tonne gantry crane, the wheeled excavator, the 20-tonne single clamp, the 2x20-tonne double clamp and the overturning and free fall platforms, a reliable 10-kg precision load cell was crucial to weigh prototypes during testing. Prototypes were weighed before the tests to measure the initial mass; thus, RLM was measured during the tests with a precision of $0.1 \%$. During the prototype drop tests, the operation which was most time-consuming was the weighing of prototypes, because the load cell is a sensitive instrument which requires gentle maneuvers which are not compatible with dropping 15tonne prototypes. To weigh prototypes during free fall tests, the load cell had to be manually inserted and then removed to drop prototypes; thus, to reduce the number of load cell inserting-removing operations, different prototypes were dropped in a row and then weighed in a row. In addition to quantitative prototype weight measurements, visual inspection was routinely done to detect cracks in CAU prototypes and platforms, and to obtain a qualitative estimation of prototype loss of mass. If the visual estimation of prototype loss of mass was lower than the $10 \mathrm{~kg}$, precision of the load cell, the RLM was considered null.

\section{Overturning test results}

Two 15-tonne cube prototypes (C-08 and C-09) and four 16-tonne Cubipod prototypes (P-08, P09, P-10 and P-11) were used for overturning. The gantry crane with the appropriate clamp took the prototypes from the stacking area or the ground and placed it on the 90-cm thick reinforced- 
concrete overturning platform; then, a wheeled excavator maneuvered the unit to generate the desired prototype overturning movements. In the case of complete overturning of cube (see Fig. 2b), the wheeled excavator inclined cube prototype $\mathrm{C}-08$ more than $45^{\circ}$ to generate overturning and its impact on the platform; the prototype was weighed every 8 impacts up to 24 , when a 2.0\% RLM was measured. Cube prototype C-07 was used for partial overturning (see Figs. 2a); the wheeled excavator released the cube prototype when it was inclined $15^{\circ}$; an almost negligible $0.4 \%$ RLM was measured after 24 partial overturning impacts. Partial and complete overturning tests only slightly damaged the edges of cube prototypes.

The wheeled excavator was used also to overturn Cubipod prototypes, but the maneuver was done differently. Prototypes P-09 and P-10 were used for frontal overturning. The wheeled excavator symmetrically pushed the Cubipod prototype to overturn it, but two rebounds on the platform usually occurred generating many low intensity impacts; prototype loss of mass was negligible up to 25 pushes. Similarly, prototypes P-08 and P-11 were used for diagonal overturning; in these tests, the excavator's force was applied asymmetrically to generate a diagonal overturn. Table 1 describes the characteristics of prototype overturning tests and shows the RLM corresponding to 15-tonne cube and 16-tonne Cubipod prototypes; only cube complete overturning test causes minor but significant loss of mass (RLM=2.0\%), after 24 impacts.

\section{[Insert Table 1 here]}

The overturning platform was in excellent condition during the tests. It was evident that low energy impacts with drop heights below $\mathrm{h}[\mathrm{m}]=0.20$ caused null or negligible damage in prototypes; however, drop heights above $\mathrm{h}[\mathrm{m}]=0.50$ could cause significant accumulative damage in cube prototypes. Cubipod free fall tests started with a drop height $h[\mathrm{~m}]=2.0$ and 
cube free fall tests began with a drop height $\mathrm{h}[\mathrm{m}]=0.50$.

\section{Free fall test results}

Six 15-tonne cube prototypes (C-01 to C-04, C-06 and C-07) and six 16-tonne Cubipod prototypes (P-01 and P-03 to P-07) were used for the free fall and extreme free fall tests. In these tests, the gantry crane with the appropriate clamp took the prototypes from the stacking area or the ground, hung it over the free fall platform at the prescribed drop height, and released it when the personnel was behind the safety perimeter and the video camera was recording. Figs. 3 to 5 outline the $\mathrm{AD}, \mathrm{ED}$ and $\mathrm{RD}$ free fall tests for cube and Cubipod prototypes, which were dropped on the most robust $1.15 \mathrm{~m}$-thick reinforced-concrete free fall platform covered with a $20 \mathrm{~mm}$ steel plate. The prototypes were weighed before and after each drop to estimate the loss of mass. Table 2 shows the percentage of RLM corresponding to the free fall tests, ordered by time (date/hour) with a qualitative description of the free fall platform. In the case of the two extreme free fall tests, the dropped prototype fell on to four Cubipod prototypes placed on the overturning platform. During the free fall tests, small damages in the free fall platform accumulated to the point of being clearly visible (noted as "damages" in Table 2) and deteriorating the platform and the protecting steel plate later (noted as "poor" in Table 2).

Cubipod prototype P-07 was first used for three ED tests from $\mathrm{h}[\mathrm{m}]=2.0$; Cubipod P-05 was used later for three $\mathrm{AD}$ tests from $\mathrm{h}[\mathrm{m}]=2.0$; cube prototype $\mathrm{C}-06$ was then used for two $\mathrm{AD}$ tests from $\mathrm{h}[\mathrm{m}]=0.5$, and so on. Cubipod and cube prototypes were alternatively dropped on the free fall platform (see Table 2) to compensate the slight but progressive deterioration of the free fall platform during the tests. For any given prototype, the maximum number of drops on the free fall platform was six $(n=6)$, but the scheduled free fall tests was stopped if the loss of mass of the prototype was so important as to significantly change the morphology of the CAU. 
The measured RLM shown in Table 2 was clearly dependent on the drop height, number of drops and armor unit; however, Cubipod prototype P-03 was the exception. P-03 was dropped from $\mathrm{h}[\mathrm{m}]=3.0$ and it should have been severely damaged; however, no damage was observed other than a sharp deterioration of the free fall platform. Apparently, the energy of this and the successive drops of Cubipod P-03 from $\mathrm{h}[\mathrm{m}]=3.0$ accumulated damage in the free fall platform instead of accumulating damages in the prototype itself. P-03 was then dropped from $\mathrm{h}[\mathrm{m}]=3.0$ on the still good looking overturning platform, but the prototype punched the $90-\mathrm{cm}$ thick reinforced-concrete platform making evident that a steel plate is necessary to protect free fall platforms from punching.

\section{[Insert Table 2 here]}

Table 2 shows a clear damage pattern: RLM increases with the drop height (energy of the impact) and the number of drops, while Cubipod resisted higher drops than cube prototypes. $\mathrm{AD}$ tests caused more damage than $\mathrm{ED}$ and $\mathrm{RD}$ tests in both cube and Cubipod prototypes. Additionally, measured RLM was either RLM $<3.7 \%$ or RLM $>20 \%$ with breakage and change in the morphology of armor unit. Both cube and Cubipod prototypes showed minor damages which increased when drop height and number of drops increased; however, if accumulated RLM was higher than 4\%, the prototypes broke, affecting the morphology of the CAUs.

In order to describe the observed RLM in these prototype drop tests, Corredor et al. (2008) postulate a conceptual model based on potential energy being distributed in three parts: (1) local edge damages, (2) internal cracks and (3) dissipation. Firstly, a part of the prototype potential energy generates very intense and localized surface pressure and local crushes during the impact which may cause a small loss of mass in edges or vertices, but without 
affecting the core of the CAU. Secondly, if deceleration is intense enough during impact, internal cracks may be generated and fracture planes are favored, which can affect the core of the prototype changing its morphology. Finally, some dissipation of energy always occurred associated with soil and platform damping, platform damages, noise, friction with air and soil, etc. Cubipod units used in different drop tests tended to consume more energy for local edge damages, while cube units tended to generate face-to-platform impacts with higher accelerations and more internal cracks; this explains why Cubipods resist higher drops than cube units although both are massive CAUs and cubes resist the highest static loads. Corredor et al. (2008) propose the use of the equivalent drop height given by Eq. 1 to take into account both the drop height and the number of drops simultaneously

$$
h_{e}=h \sqrt[4]{n}
$$

in which $h$ is the drop height; $h_{e}$ is the equivalent drop height, and $\mathrm{n}$ is the number of drops. On the one hand, if the equivalent drop height is lower than a certain threshold limit, $\mathrm{h}_{\mathrm{e}}<\mathrm{h}_{\mathrm{e} 0}[\mathrm{~m}]=0.5$ for cube and $\mathrm{h}_{\mathrm{e}}<\mathrm{h}_{\mathrm{e} 0}[\mathrm{~m}]=1.9$ for Cubipod, prototypes only showed local edge damages and very low RLM. On the other hand, if the equivalent drop height is higher than a critical limit, $h_{e}>h_{e c}[m]=1.9$ for cube and $h_{e}>h_{e c}[m]=3.1$ for Cubipod, prototypes break causing RLM $>20 \%$ and a significant change in the morphology of the CAU. If equivalent drop height is between, $\mathrm{h}_{\mathrm{e} 0}<\mathrm{h}_{\mathrm{e}}<\mathrm{h}_{\mathrm{ec}}$, local edge damages as well as significant internal cracks are generated with RLM $<4 \%$. Fig. 6 shows a linear relationship between equivalent drop height and RLM, for the range $\mathrm{h}_{\mathrm{e} 0}<\mathrm{h}_{\mathrm{e}}<\mathrm{h}_{\mathrm{ec}}$, in which $\mathrm{RLM}=0 \%$ for $\mathrm{h}_{\mathrm{e}}=\mathrm{h}_{\mathrm{e} 0}$ and $\mathrm{RLM}=4 \%$ for $\mathrm{h}_{\mathrm{e}}=\mathrm{h}_{\mathrm{ec}}$.

\section{[Insert Fig. 6 here]}

Four cube and one Cubipod prototypes (C-01, C-03, C-04, C-05 and P-05) were broken during the free fall tests; in these cases, values of RLM $>20 \%$ were measured as well as CAU morphological changes observed. Fig. 7 shows pictures of the broken prototypes; in all cases, 
breakage occurred when one or several inclined fracture planes affected the core of the unit.

\section{[Insert Fig. 7 here]}

\section{Extreme free fall test results}

In addition to the overturning and free fall tests, two Cubipod prototypes (P-01 and P-04) were used for extreme free fall tests, in which a 16-tonne cube prototype is dropped only one time from the maximum drop height on a group of four 16-ton Cubipod prototypes placed on the 90$\mathrm{cm}$ thick reinforced-concrete overturning platform. RLM was measured for both the dropped prototype and the four receptor prototypes. The extreme free fall tests emulated the accidental fall of a CAU on an armor layer during construction. Figs. 8a and $8 b$ show the schemes of the extreme anvil drop test (EAD) and the extreme edge drop test (EED), respectively.

\section{[Insert Fig. 8 here]}

After completing overturning and free fall tests, the $90-\mathrm{cm}$ thick overturning platform was still in excellent condition. Four Cubipod prototypes (P-02, P-06, P-09 and P-11) with null or negligible damages were selected to form a receptor group of prototypes and were placed on the overturning platform. P-04 Cubipod prototype was selected for the EAD test and elevated to almost the maximum limit of the gantry crane $h[m]=8.5$. After weighing the five armor units, the four receptor prototypes were re-grouped on the platform to receive the impact of P-01 Cubipod prototype in the EED test; the drop height for EED test was $\mathrm{h}[\mathrm{m}]=9.5$, higher than the drop height of EAD test because the clamp and auxiliary chains required less space for EED tests.

\section{[Insert Table 3 here]}

Extreme free fall tests caused significant damages to both the dropped and the receptor prototypes; however, no breakage occurred. Only minor damages were measured but it did not significantly change the morphology of the CAUs. The dropped units impacted on top of the receptor prototype group; thus, the liberated potential energy of the EAD and EED tests corresponded approximately to drop heights $\mathrm{h}[\mathrm{m}]=7.0$ and $\mathrm{h}[\mathrm{m}]=8.0$, respectively. The 
kinetic energy of the dropped unit seemed to be distributed among the five armor units causing CAU damages which would roughly correspond to individual drop heights in the range $1.5<\mathrm{h}[\mathrm{m}]<2.5$.

\section{Summary and conclusions}

Armor unit integrity must be guaranteed at prototype scale because Froude's scaled models used to assess the hydraulic stability of CAUs do not properly reproduce the material stress limit. Stresses in the CAUs increase with the CAU size making them more fragile when the design wave climate is more severe; thus, to assure CAU integrity, large unreinforced massive CAUs or fully reinforced slender CAUs are used for breakwaters under the severest design wave conditions.

Numerical 3D static and dynamic FEM and instrumented small scale physical models have been used to estimate the structural stress levels in CAU, but they have serious limitations to represent real conditions. On the contrary, full scale instrumented prototypes and prototype drop test experiments are very expensive and much more difficult to control, but results are more likely to represent almost real conditions. In this paper, a methodology to assess the structural strength of the new massive CAU, the Cubipod, is justified, comparing prototype drop test results with those of conventional cubic blocks widely used as massive CAU for mound breakwaters. 15-tonne cube and 16-tonne Cubipod CAUs were manufactured with similar concrete to make the drop test results comparable.

Both the methodology and experimental drop test design were based on the methodologies used for prototype drop tests of other armor units but adapted to the available facilities and 
specific conditions of the Cubipod armor unit. A vertical casting system was designed by SATO's technicians, in which the upper part of the molds was lifted six hours after vibration to match the two-unit/day production rate of conventional cubes. Eight 15-tonne cubes and eleven 16-tonne Cubipods were manufactured and stacked in January 2008 and prototype drop tests were completed the first week of March 2008. The main facilities and equipment used for the prototype drop tests were: the block yard with a 65/25-tonne gantry crane of the Port of Alicante (Spain), one reinforced concrete overturning platform (10.0x7.5x0.9 m), one reinforced concrete free-fall platform $(5.0 \times 5.0 \times 1.15 \mathrm{~m})$ protected with a $20-\mathrm{mm}$ thick steel plate, one wheeled excavator, one 20-tonne single clamp, one 20x20-tonne double clamp and a 10-kg precision load cell to measure loss of mass during drop tests.

Overturning and free fall tests were inspired in the prototype drop tests of other CAUs and designed to emulate the scenarios of collisions between units when rocking or rolling as well as unit collisions during handling, transport and placing on the armor layer, respectively. Cubes and Cubipods suffered only minor damages in overturning tests with RLM lower than 2\% and $0.3 \%$, respectively. The measured RLM in free fall tests was dependent on factors related to $\mathrm{CAU}$, drop type, $\mathrm{h}$ and $\mathrm{n}$; an equivalent drop height $\left(h_{e}\right)$ is proposed to take into account $\mathrm{h}$ and $\mathrm{n}$ simultaneously. If the equivalent drop height is lower than a certain threshold limit, $\mathrm{h}_{\mathrm{e}}<\mathrm{h}_{\mathrm{e} 0}[\mathrm{~m}]=0.5$ for cubes and $\mathrm{h}_{\mathrm{e}}<\mathrm{h}_{\mathrm{e} 0}[\mathrm{~m}]=1.9$ for Cubipods, prototypes only showed very low RLM and local edge damages. If the equivalent drop height is higher than a critical limit, $h_{e}>h_{e c}[m]=1.9$ for cubes and $h_{e}>h_{e c}[m]=3.1$ for Cubipods, prototypes break causing RLM $>20 \%$ and a significant change in the morphology of the CAU. Finally, if equivalent drop height is between $\mathrm{h}_{\mathrm{e} 0}<\mathrm{h}_{\mathrm{e}}<\mathrm{h}_{\mathrm{ec}}$, local edge damages and also significant internal cracks are generated with $\mathrm{RLM}<4 \%$. Additionally, two Cubipod prototypes were tested from the maximum elevation of the gantry crane, $\mathrm{h}[\mathrm{m}]=8.5(\mathrm{EAD})$ and $\mathrm{h}[\mathrm{m}]=9.5(\mathrm{EED})$; neither was 
broken because the impact energy was apparently distributed among the dropped prototype and the four Cubipods which received the impact.

\section{Acknowledgements}

The authors are grateful for the logistic support provided by the Port Authority of Alicante and the consortium TMS. Financial support was received from CDTI (CUBIPOD Project). The authors also thank Roman Goumy for his assistance during the prototype drop tests and Debra Westall for revising the manuscript. 


\section{Notation}

The following symbols and acronyms are used in this paper:

$\mathrm{AD}=$ anvil drop;

$\mathrm{CV}=$ coefficient of variation;

$\mathrm{ED}=$ edge drop;

$\mathrm{EAD}=$ extreme anvil drop;

$\mathrm{EED}=$ extreme edge drop;

FEM $=$ Finite Element Method;

$\mathrm{H}=$ wave height;

$\mathrm{h}=$ drop height;

$\mathrm{h}_{\mathrm{e}}=$ equivalent drop height;

$\mathrm{h}_{\mathrm{e} 0}=$ equivalent drop height threshold limit;

$\mathrm{h}_{\mathrm{ec}}=$ critical equivalent drop height;

$\mathrm{HeP}=$ Heterogeneous Packing;

Hs = significant wave height;

$\mathrm{IDa}=$ initiation of damage;

$\mathrm{IDe}=$ initiation of destruction;

$\mathrm{K}_{\mathrm{D}}=$ stability coefficient;

$\mathrm{n}=$ number of drops;

$\mathrm{RD}=$ random drop;

$\mathrm{RLM}=$ relative loss of mass. 


\section{References}

Burcharth, H.F. (1981). Full scale dynamic testing of dolosse to destruction. Coastal Engineering, 4(3):229-251.

Burcharth, H.F., and Brejnegaard-Nielsen, T. (1986). The influence of waist thickness of dolosse on the hydraulic stability of dolosse armour. Proc., $20^{\text {th }}$ Int. Conf. on Coastal Engineering, ASCE, 1783-1796.

Burcharth, H.F., Howell, G.L., and Liu, Z. (1991). On the determination of concrete armour unit stresses including specific results related to Dolosse. Coastal Engineering, 15(12):107-165.

Burcharth, H.F., d'Angremond, K., Van der Meer, J.W., and Liu, Z. (2000). Empirical formula for breakage of Dolosse and Tetrapods. Coastal Engineering, 40(3):183-206.

Burcharth, H.F., Maciñeira, E., and Canalejo, P. (2002). Model testing and reliability evaluation of the new deepwater breakwater at la Coruña, Spain. Proc., $28^{\text {th }}$ Int. Conf. on Coastal Engineering, ASCE, 1581-1593.

Corredor, A., Torres, R., Miñana, J.V., Fernández, E., Menéndez, C.F., Santos, M., GómezMartín, M.E., Goumy, R., and Medina, J.R. (2008). CUBÍPODO: Estudios de estabilidad hidráulica 2D y 3D, estudio del remonte y rebase, diseño del encofrado y ensayos de caída de prototipos. Libro del III Congreso Nacional de la Asociación Técnica de Puertos y Costas, Puertos del Estado, 187-211 (in Spanish).

Dupray, S., and Roberts, J. (2009). Review of the use of concrete in the manufacture of concrete armour units. Proc. of Coasts, Marine Structures and Breakwaters 2009, ICE, (in press).

Gómez-Martín, M.E., and Medina, J.R. (2006). Damage progression on cube armored breakwaters. Proc., $30^{\text {th }}$ Int. Conf. on Coastal Engineering, ASCE, 5229-5240. 
Gómez-Martín, M.E., and Medina, J.R. (2007). Cubipod concrete armor unit and heterogeneous packing. Proc., $5^{\text {th }}$ Coastal Structures Int. Conf., World Scientific, 140-151.

Gómez-Martín, M.E., and Medina, J.R. (2008). Erosion of cube and Cubipod armor layers under wave attack. Proc., $31^{\text {st }}$ Int. Conf. on Coastal Engineering, ASCE, 3461-3473.

Hakenberg, R., Vos-Rovers, I., Reedijk, J.S., and Muttray, M. (2004). Structural Integrity of the $\mathrm{Xbloc}{ }^{\circledR}$ breakwater armour units prototype and numerical droptests. Proc. $29^{\text {th }}$ Int. Conf. on Coastal Engineering, ASCE, 4507-4520.

Hanzawa, M., Kato, T., Kishira, Y., Ozawa, Y., Niidome, Y., Murakami, T., Ono, A., Hidaka, K., Yoshida, H., and Tanaka, I. (2006). Fully reinforced 80t Dolos and sloping top caisson in Hososhima Port. Proc. 30 $0^{\text {th }}$ Int. Conf. on Coastal Engineering, ASCE, 4805-4814.

Howell, G.L. (1998). Measurement of forces on Dolos armor units at prototype scale. Proc. $26^{\text {th }}$ Int. Conf. on Coastal Engineering, ASCE, 2355-2369.

Iribarren, R. (1938). A formula for the calculation of rock fill dykes. (Translation of "Una fórmula para el cálculo de los diques de escollera", The Bulletin of the Beach Erosion Board, Jan 1949, 3(1):1-15.

Latham, J.-P., and Xiang, J. (2009). Application of the finite-discrete element method to dynamic stress development in armour units and armour layers. Proc. Coasts, Marine Structures and Breakwaters 2009, ICE, (in press).

Lillevang, O.J., and Nickola W.E. (1976). Experimental studies of stresses within the breakwater armor piece "Dolos". Proc., 15 th Int. Conf. on Coastal Engineering, ASCE, $2519-2543$

McDougal, W.G., Melby, J.A., and Tedesco, J.W. (1988). Wave forces on concrete armor units. Journal of Waterway, Port, Coastal and Ocean Engineering, 114(5): 582-598. 
Medina, J.R., Gómez-Martín, M.E., Corredor, A., Torres, R., Miñana, J.V., Fernández, E., Menéndez, C.F., and Santos, M. (2009). Cube and Cubipod armour unit drop tests and cost analysis. Proc. of Coasts, Marine Structures and Breakwaters 2009, ICE, (in press).

Melby, J.A., and Turk G.F. (1995). CORE-LOC: Optimized concrete armor units. PIANC Bulletin $\mathrm{N}^{\circ} 87,5-19$.

Muttray, M., Reedijk, J.S., Vos-Rovers, I., and Bakker, P. (2005). Placement and structural strength of $\mathrm{Xbloc}{ }^{\circledR}$ and other single layer armor units. Proc., Coastlines, Structures and Breakwaters 2005, ICE, 556-567.

Nishigori, W., Endo, T., and Shimada, A. (1986). On stress in Tetrapods under wave action. Proc., $20^{\text {th }}$ Int. Conf. on Coastal Engineering, ASCE, 2119-2132.

Nishigori, W., Endo, T., Nemoto, K., Noguchi, Y., and Yamamoto, M. (1989). Similarity law of impact between model and prototype tetrapds, in Stresses in Concrete Armor Units, edited by Davidson D.D. and Magoon O.T., ASCE, 107-122.

Scott, D., Turcke, D., and Baird, W.F. (1990). Structural modelling of Dolos armor units. Journal of Waterway, Port, Coastal and Ocean Engineering, 116(1):120-136.

Silva, M.A.G. (1983). On the mechanical strength of cubic armour blocks. Proc., Coastal Structures' 83, ASCE, 259-271.

SPM (1975). Shore Protection Manual, U.S. Army Coastal Engineering Research Center, Fort Belvoir, Virginia, USA.

Tedesco, J.W., McGill P.B., Melby, J.A., and McDougal, W.G. (1988). Structural Response

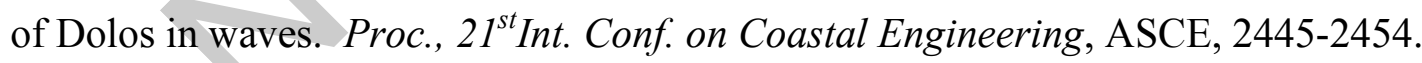

Tedesco, J.W., McDougal, W.G., Bloomquist, D., and Consolazio, G. (2003). Response of concrete armor units to wave-induced impact. Computers and Structures, 81(8-11):963981. 
Turk, G.F.., and Melby, J.A (1994). The large scale Dolos flume study. Proc., $24^{\text {th }}$ Int. Conf. on Coastal Engineering, ASCE, 1641-1656.

Turk, G.F.., and Melby, J.A (1998). Impact structural response of CORE-LOC. Proc., $26^{\text {th }}$ Int. Conf. on Coastal Engineering, ASCE, 1846-1856.

\section{LIST OF TABLES}

Table 1. Relative loss of mass (\%) in cube and Cubipod overturning tests.

Table 2. Timing for free fall tests, relative loss of mass (\%) and platform state.

Table 3. Relative loss of mass (\%) in Cubipod extreme free fall tests.

\section{LIST OF FIGURES}

Figure 1. Pictures of prototype casting systems: (a) Cubipod and (b) cube.

Figure 2. Cube overturning tests: (a) partial overturning and (b) complete overturning.

Figure 3. Anvil Drop (AD) tests: (a) cube and (b) Cubipod.

Figure 4. Edge Drop (ED) tests: (a) cube and (b) Cubipod.

Figure 5. Random Drop (RD) tests: (a) cube and (b) Cubipod.

Figure 6. Relative loss of mass (\%) in cube and Cubipod prototype drop tests.

Figure 7. Fracture planes of broken cube and Cubipod prototypes.

Figure 8. Schemes of Cubipod extreme free fall tests: (a) EAD test and (b) EED test. 
Table 1. Relative loss of mass (\%) in cube and Cubipod overturning tests.

\begin{tabular}{|c|c|c|c|c|c|c|}
\hline \multirow{2}{*}{$\begin{array}{c}\text { mass } \\
\text { (tonne) }\end{array}$} & \multicolumn{3}{|c|}{ CUBE } & \multicolumn{3}{|c|}{ number of impacts (n) } \\
\hline & Prototype & test & $\mathrm{h}(\mathrm{cm})$ & 8 & 16 & 24 \\
\hline 15.41 & C-08 & complete & 39 & $1.1 \%$ & $1.8 \%$ & $2.0 \%$ \\
\hline 15.22 & 07 & partial & 20 & $0.1 \%$ & $0.1 \%$ & $0.4 \%$ \\
\hline \multirow{2}{*}{$\begin{array}{c}\text { mass } \\
\text { (tonne) }\end{array}$} & \multicolumn{3}{|c|}{ CUBIPOD } & \multicolumn{3}{|c|}{ number of strikes (n) } \\
\hline & Prototype & test & $\mathrm{h}(\mathrm{cm})$ & 13 & 19 & 25 \\
\hline 16.65 & P-09 & frontal & 13 & $=$ & $=$ & $0.1 \%$ \\
\hline 16.49 & $\mathbf{P}-10$ & frontal & 13 & $=$ & $=$ & $=$ \\
\hline \multirow{2}{*}{$\begin{array}{c}\text { mass } \\
\text { (tonne) }\end{array}$} & \multicolumn{3}{|c|}{ CUBIPOD } & \multicolumn{3}{|c|}{ number of strikes (n) } \\
\hline & Prototype & test & $\mathrm{h}(\mathrm{cm})$ & 20 & 40 & 60 \\
\hline 16.54 & $\mathrm{P}-08$ & diagonal & 13 & $=$ & $=$ & $0.1 \%$ \\
\hline 16.52 & $\mathrm{P}-11$ & diagonal & 13 & $=$ & $0.2 \%$ & $0.2 \%$ \\
\hline
\end{tabular}

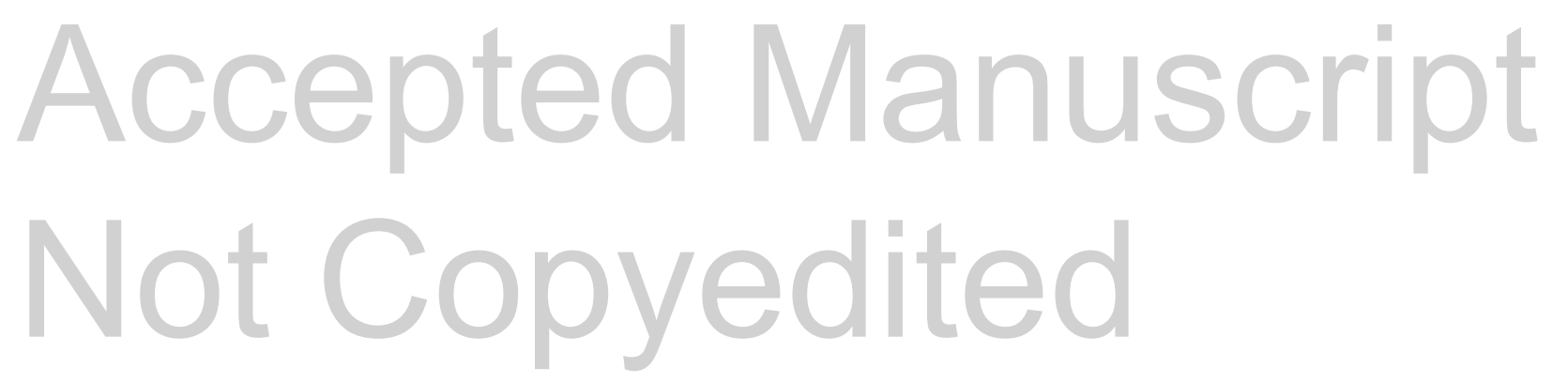


Table 2. Timing for free fall tests, relative loss of mass (\%) and platform state.

\begin{tabular}{|c|c|c|c|c|c|c|c|c|c|c|c|c|c|c|c|c|}
\hline \multicolumn{3}{|c|}{ Prototype identification } & C-06 & C-02 & C-01 & C-03 & C-04 & C-05 & C-07 & $\mathrm{P}-01$ & $\mathrm{P}-04$ & P-03 & $\mathrm{P}-05$ & $\mathrm{P}-07$ & P-06 & \\
\hline \multicolumn{3}{|c|}{ Prototype mass (tonne) } & 15.35 & 15.18 & 15.37 & 15.00 & 15.46 & 15.51 & 15.15 & 16.59 & 16.65 & 16.66 & 16.67 & 16.66 & 16.66 & \\
\hline \multicolumn{3}{|c|}{ Prototype drop test } & $A D$ & $\mathrm{AD}$ & $\mathrm{AD}$ & $A D$ & ED & ED & RD & EED & EAD & $\mathrm{AD}$ & $\mathrm{AD}$ & ED & RD & \\
\hline \multicolumn{3}{|c|}{ Drop height (cm) } & 50 & 100 & 150 & 200 & 200 & 200 & 190 & 950 & 850 & 300 & 200 & 200 & 190 & \\
\hline DATE & TIME & Order & C-06 & $\mathrm{C}-02$ & C-01 & $\mathrm{C}-03$ & C-04 & C-05 & C-07 & $\mathrm{P}-01$ & P-04 & $\mathrm{P}-03$ & $\mathrm{P}-05$ & $\mathrm{P}-07$ & P-06 & platform \\
\hline \multirow{3}{*}{$\begin{array}{c}\text { March 4, } \\
2008\end{array}$} & 18:00 & 1 & & & & & & & & & & & & 0.1 & & good \\
\hline & $18: 30$ & 2 & & & & & & & & & & & & 0.3 & & good \\
\hline & 19:00 & 3 & & & & & & & & & & & & 0.8 & & good \\
\hline \multirow{12}{*}{$\begin{array}{c}\text { March 5, } \\
2008\end{array}$} & $12: 50$ & 4 & & & & & & & & & & & 0.1 & & & good \\
\hline & $13: 00$ & 5 & & & & & & & & & & & 0.5 & & & good \\
\hline & $13: 37$ & 6 & & & & & & & & & & & 0.7 & & & good \\
\hline & $14: 00$ & 7 & 0.1 & & & & & & & & & & & & & good \\
\hline & $14: 12$ & 8 & 0.5 & & & & & & & & & & & & & good \\
\hline & $14: 23$ & 9 & & & & & & 0.9 & & & & & & & & good \\
\hline & $14: 43$ & 10 & & & & & 0.3 & & & & & & & & & good \\
\hline & $14: 53$ & 11 & & & & & & & & & & & & & 0.4 & good \\
\hline & $18: 15$ & 12 & & & & & & & & & & & & & 0.8 & good \\
\hline & $18: 40$ & 13 & 0.5 & & & & & & & & & & & & & good \\
\hline & 19:08 & 14 & & & & & 32.0 & & & & & & & & & good \\
\hline & $19: 50$ & 15 & & & & & & & & & & & & & 1.0 & good \\
\hline \multirow{14}{*}{$\begin{array}{c}\text { March 6, } \\
2008\end{array}$} & $11: 10$ & 16 & 1.1 & & & & & & & & & & & & & good \\
\hline & $11: 37$ & 17 & & 0.3 & & & & & & & & & & & & good \\
\hline & $11: 45$ & 18 & & & & 45.0 & & & & & & & & & & good \\
\hline & $14: 00$ & 19 & & & & & & & & & & & & & 3.0 & good \\
\hline & $14: 16$ & 20 & & & & & & & & & & & 0.7 & & & good \\
\hline & $14: 35$ & 21 & & & & & & & & & & & 0.8 & & & good \\
\hline & $14: 43$ & 22 & & & & & & & & & & & 20.3 & & & good \\
\hline & $17: 43$ & 23 & & & & & & & & & & & & 0.8 & & good \\
\hline & 17:52 & 24 & & & & & & & & & & & & 2.7 & & good \\
\hline & $18: 04$ & 25 & 1.2 & & & & & & & & & & & & & good \\
\hline & 18:14 & 26 & & 1.5 & & & & & & & & & & & & good \\
\hline & $18: 30$ & 27 & & & 2.2 & & & & & & & & & & & good \\
\hline & $19: 50$ & 28 & & & & & & & & & & & & & 3.1 & good \\
\hline & 19:58 & 29 & & & & & & & & & & & & & 3.5 & good \\
\hline \multirow{20}{*}{$\begin{array}{c}\text { March 7, } \\
2008\end{array}$} & 08:54 & 30 & 1.4 & & & & & & & & & & & & & good \\
\hline & 09:21 & 31 & & 2.8 & & & & & & & & & & & & good \\
\hline & $09: 33$ & 32 & & & 3.3 & & & & & & & & & & & good \\
\hline & $09: 36$ & 33 & & & & & & & & & & & & 3.1 & & good \\
\hline & $11: 45$ & 34 & & 3.0 & & & & & & & & & & & & damages \\
\hline & 12:05 & 35 & & & 32.5 & & & & & & & & & & & damages \\
\hline & $12: 39$ & 36 & & 3.4 & & & & & & & & & & & & damages \\
\hline & $12: 56$ & 37 & & 3.6 & & & & & & & & & & & & damages \\
\hline & $13: 32$ & 38 & & & & & & & 0.1 & & & & & & & damages \\
\hline & $13: 41$ & 39 & & & & & & & 1.6 & & & & & & & damages \\
\hline & $14: 01$ & 40 & & & & & & & 26.7 & & & & & & & damages \\
\hline & 15:09 & 41 & & & & & & & & & & $\mathbf{x}$ & & & & damages \\
\hline & $16: 52$ & 42 & & & & & & & & & & $x$ & & & & poor \\
\hline & 17:05 & 43 & & & & & & & & & & $\mathbf{x}$ & & & & poor \\
\hline & $17: 21$ & 44 & & & & & & & & & & $\mathbf{x}$ & & & & poor \\
\hline & $17: 30$ & 45 & & & & & & & & & & $\mathbf{x}$ & & & & poor \\
\hline & $17: 42$ & 46 & & & & & & & & & & $\mathbf{x}$ & & & & poor \\
\hline & $18: 02$ & 47 & & & & & & & & & & 0.4 & & & & poor \\
\hline & 19:00 & 48 & & & & & & & & & 0.5 & \multirow{2}{*}{\multicolumn{4}{|c|}{${ }^{*}$ ) Overturning platform }} & $\operatorname{good}\left({ }^{*}\right)$ \\
\hline & 20:16 & 49 & & & & & & & & 0.9 & & & & & & $\operatorname{good}\left({ }^{*}\right)$ \\
\hline
\end{tabular}

\section{Accepted

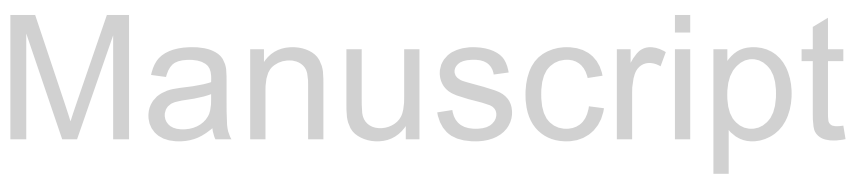

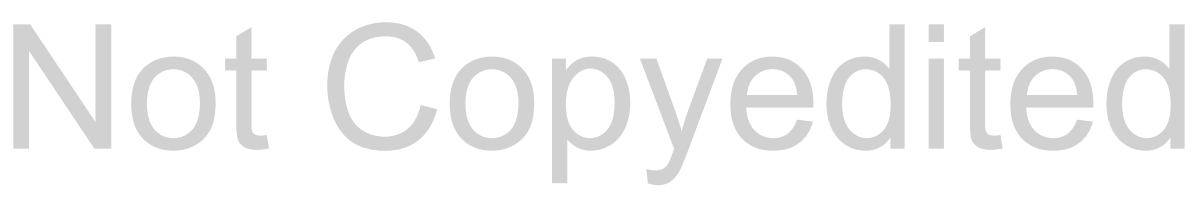


Table 3. Relative loss of mass (\%) in Cubipod extreme free fall tests.

\begin{tabular}{|c|c|c|c|c|c|c|}
\hline drop height & & \multicolumn{5}{|c|}{ Prototype identification } \\
\hline (cm) & (tonne) & P-04 & P-02 & P-06 & P-09 & P-11 \\
\hline 850 & initial mass & 16.65 & 16.40 & 16.08 & 16.63 & 16.48 \\
\hline \multirow{2}{*}{ EAD } & final mass & 16.57 & 16.25 & 16.06 & 16.60 & 16.09 \\
\cline { 2 - 7 } & RLM (\%) & $0.5 \%$ & $0.9 \%$ & $0.1 \%$ & $0.2 \%$ & $2.4 \%$ \\
\hline \hline drop height & & \multicolumn{5}{|c|}{ Prototype identification } \\
\hline (cm) & (tonne) & P-01 & P-02 & P-06 & P-09 & P-11 \\
\hline 950 & initial mass & 16.59 & 16.25 & 16.06 & 16.60 & 16.09 \\
\hline \multirow{2}{*}{ EED } & final mass & 16.45 & 16.19 & 16.05 & 16.59 & 15.92 \\
\cline { 2 - 7 } & RLM (\%) & $0.9 \%$ & $0.4 \%$ & $0.1 \%$ & $0.1 \%$ & $1.1 \%$ \\
\hline
\end{tabular}


Journal of Waterway, Port, Coastal, and Ocean Engineering. Submitted December 17, 2009; accepted June 8, 2010; posted ahead of print June 11, 2010. doi:10.1061/(ASCE)WW.1943-5460.0000064
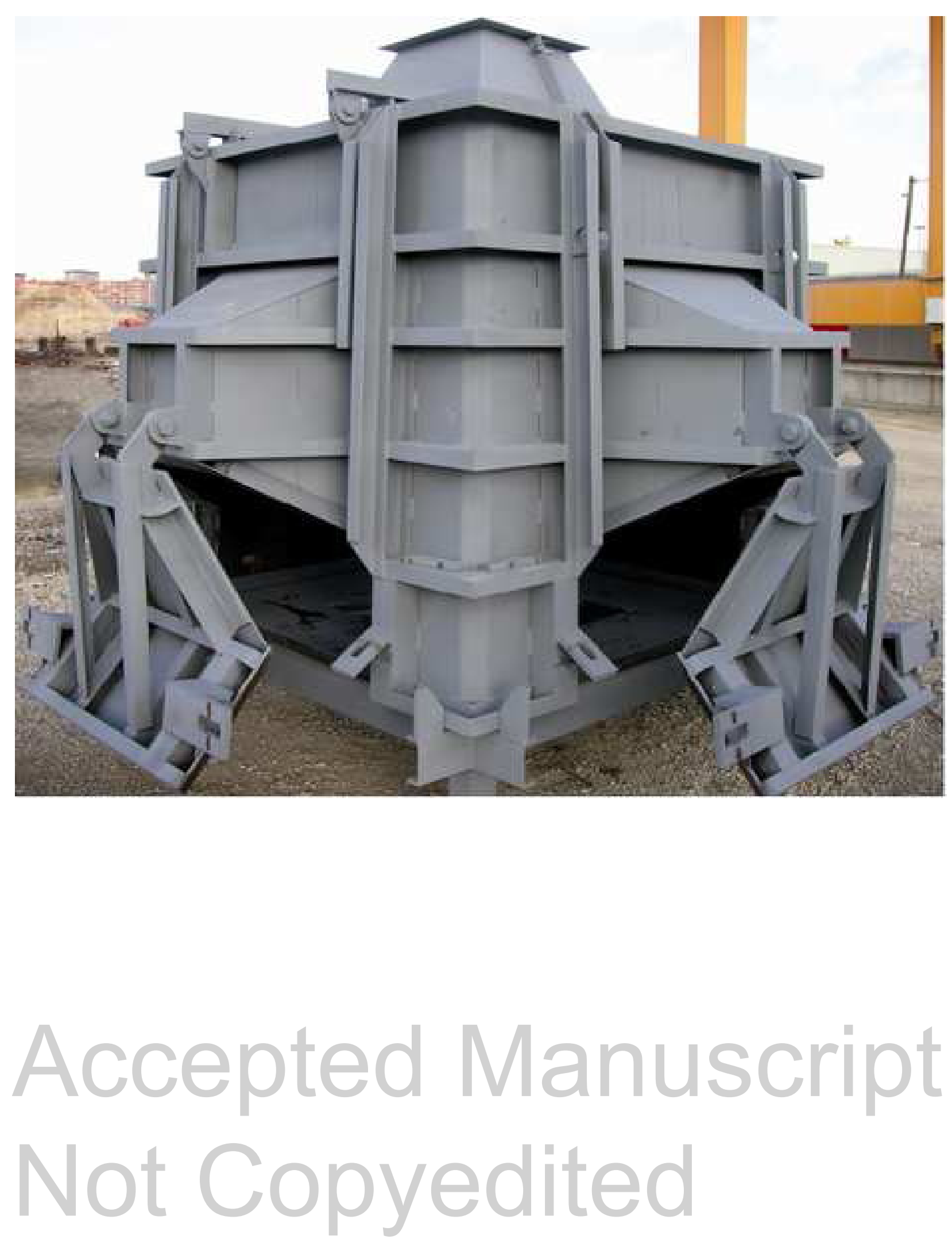
Journal of Waterway, Port, Coastal, and Ocean Engineering. Submitted December 17, 2009; accepted June 8, 2010; posted ahead of print June 11, 2010. doi:10.1061/(ASCE)WW.1943-5460.0000064

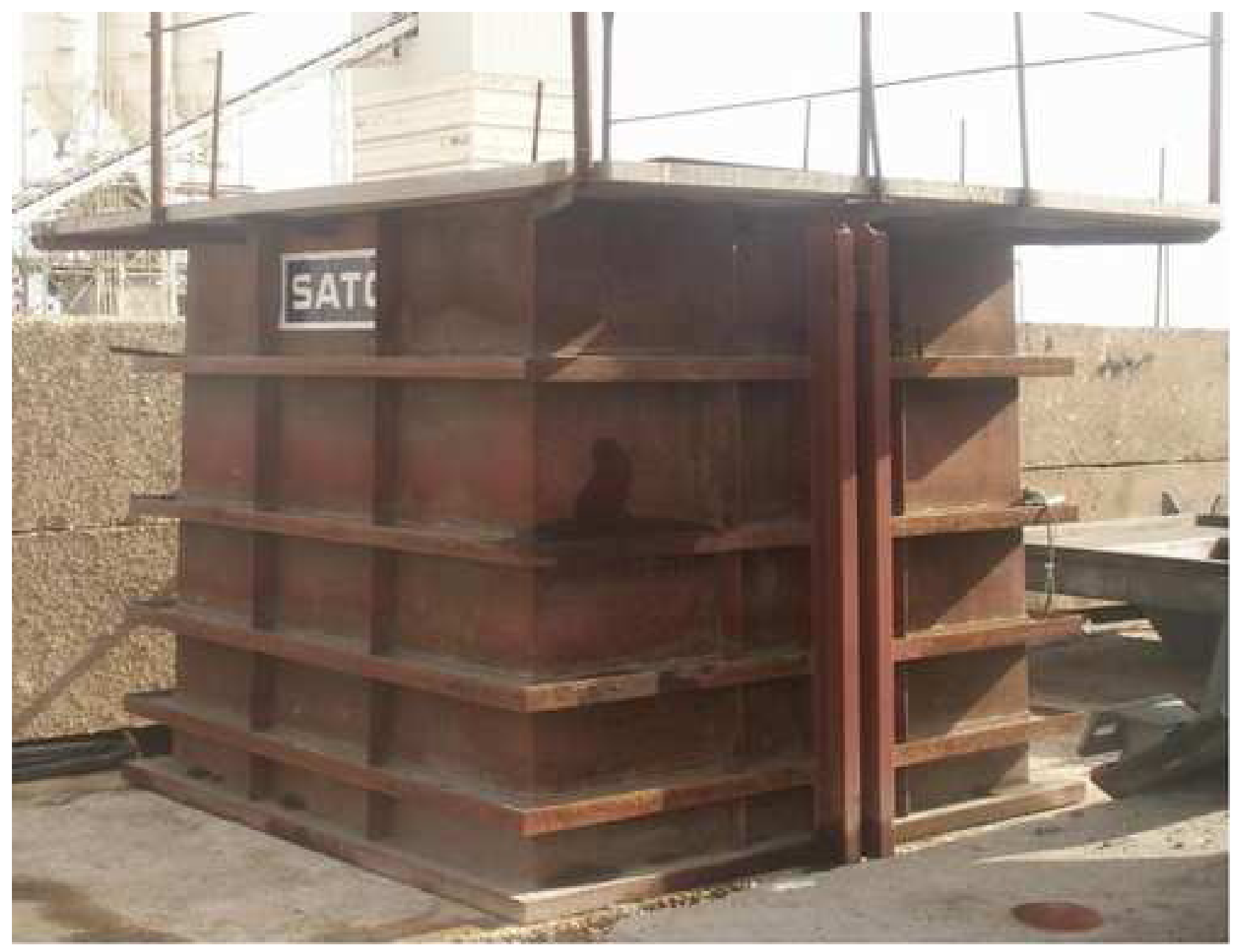

\section{Accepted Manuscript Not Copyedited}


Journal of Waterway, Port, Coastal, and Ocean Engineering. Submitted December 17, 2009; accepted June 8, 2010; posted ahead of print June 11, 2010. doi:10.1061/(ASCE)WW.1943-5460.0000064
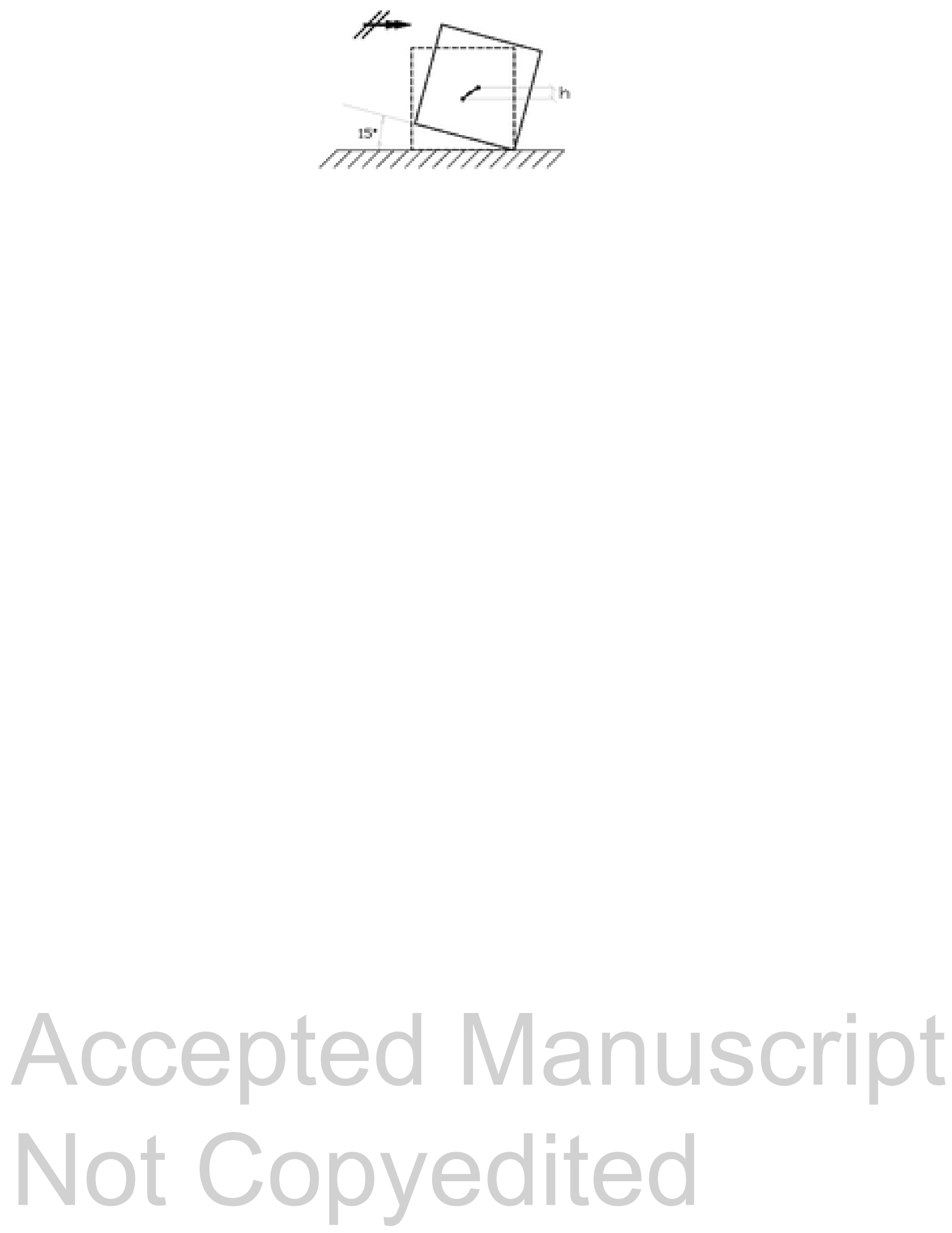

Copyright 2010 by the American Society of Civil Engineers 


\section{Figure 2b}

Journal of Waterway, Port, Coastal, and Ocean Engineering. Submitted December 17, 2009; accepted June 8, 2010; posted ahead of print June 11, 2010. doi:10.1061/(ASCE)WW.1943-5460.0000064
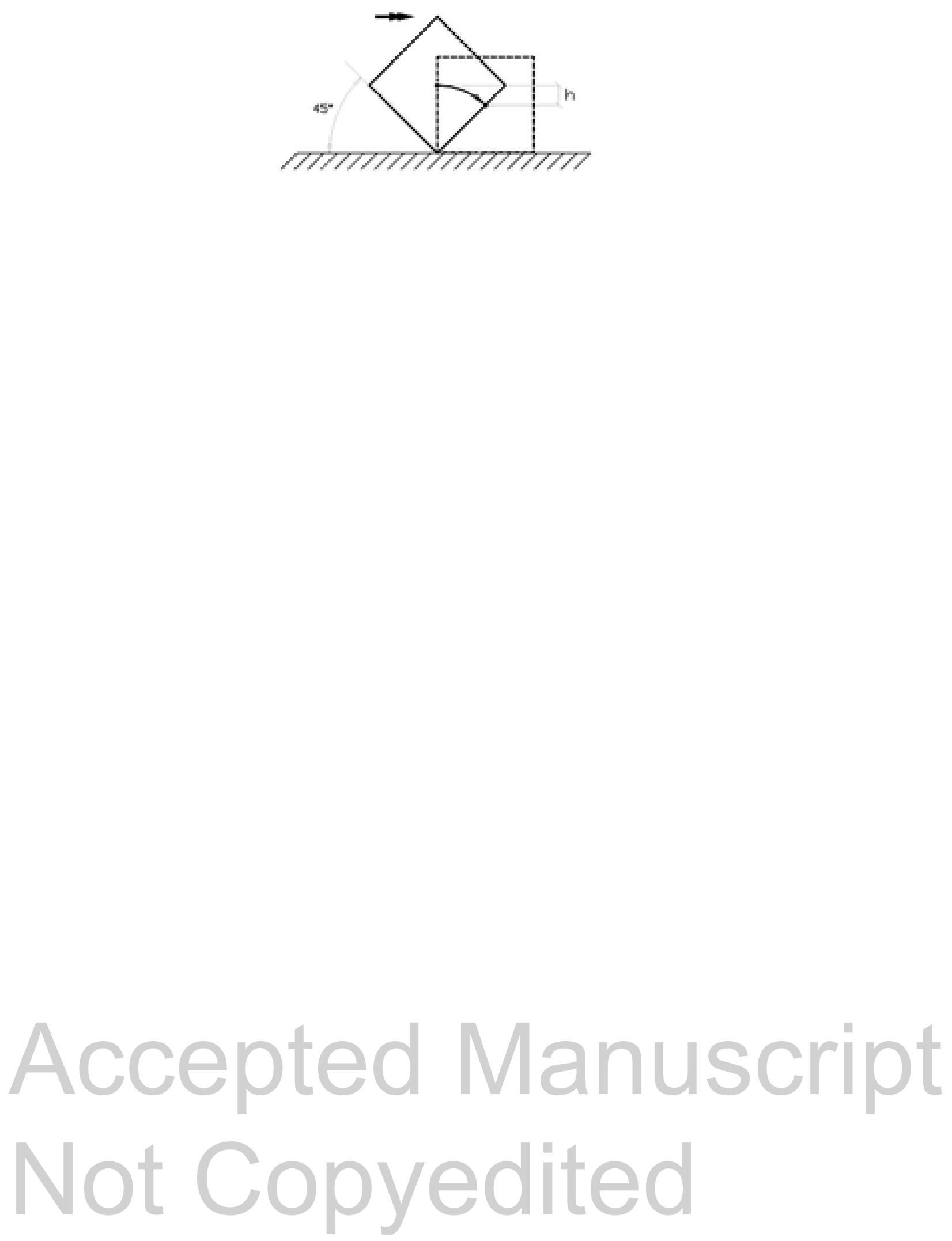
Journal of Waterway, Port, Coastal, and Ocean Engineering. Submitted December 17, 2009; accepted June 8, 2010; posted ahead of print June 11, 2010. doi:10.1061/(ASCE)WW.1943-5460.0000064
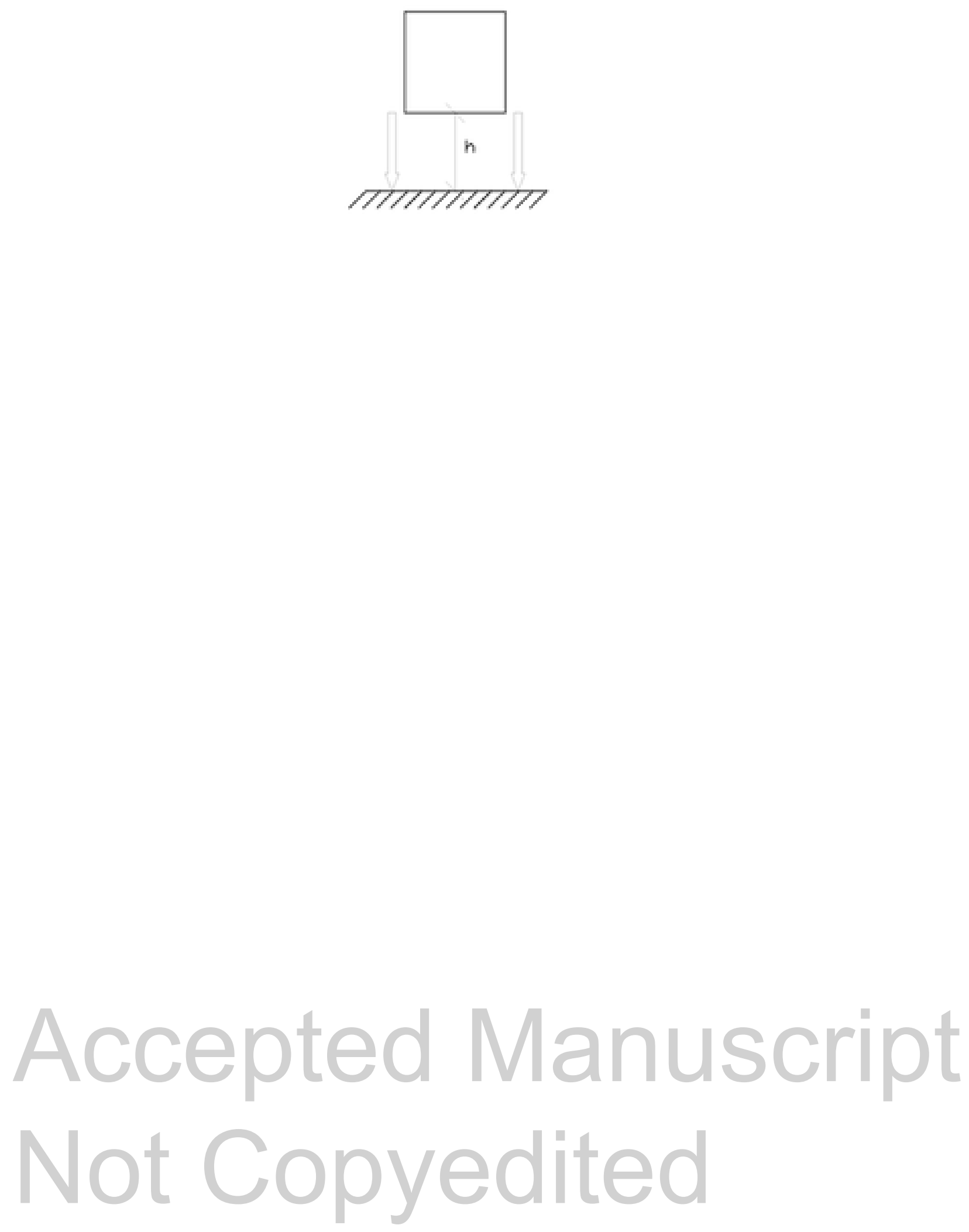

Copyright 2010 by the American Society of Civil Engineers 
Journal of Waterway, Port, Coastal, and Ocean Engineering. Submitted December 17, 2009; accepted June 8, 2010; posted ahead of print June 11, 2010. doi:10.1061/(ASCE)WW.1943-5460.0000064
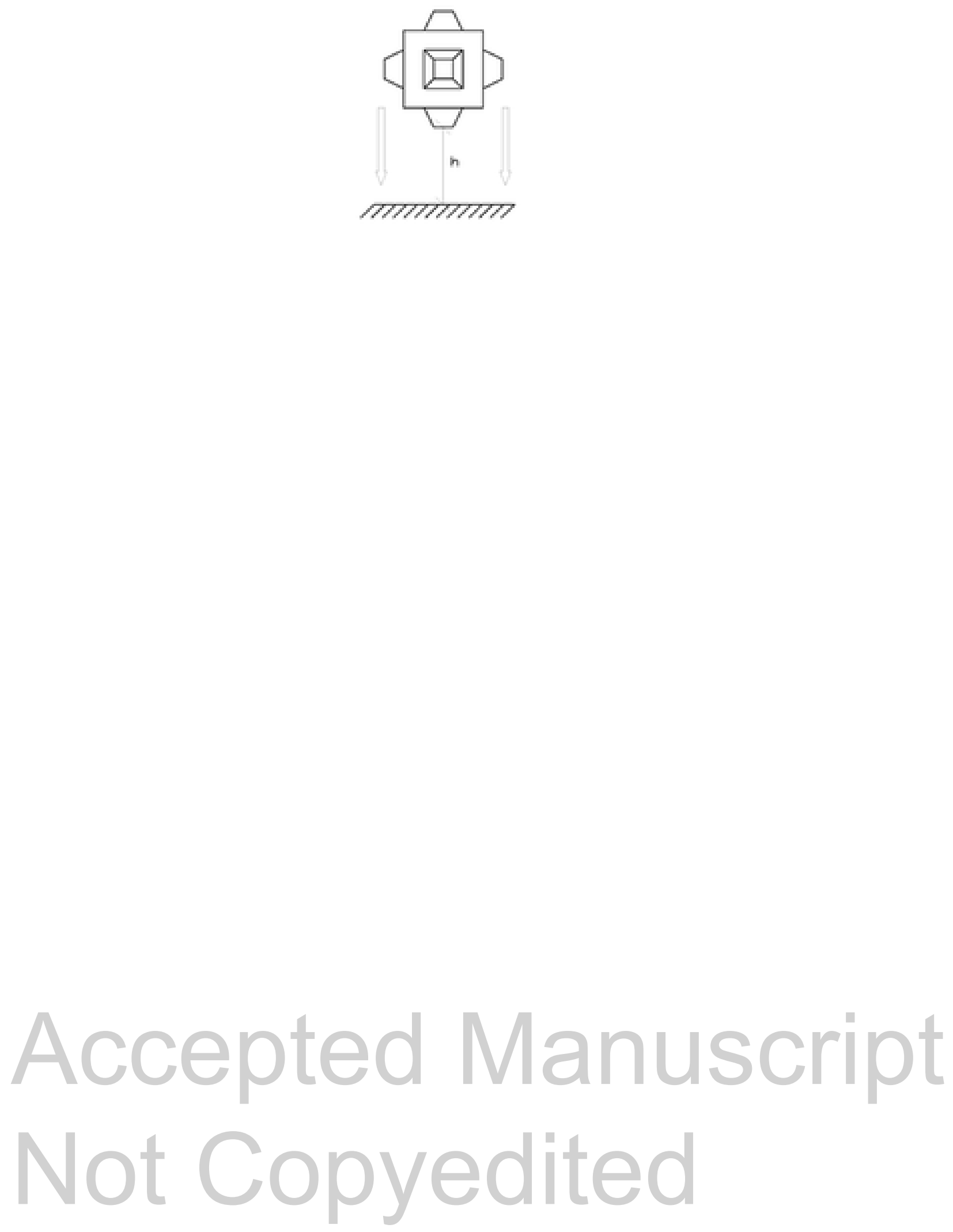

Copyright 2010 by the American Society of Civil Engineers 
Journal of Waterway, Port, Coastal, and Ocean Engineering. Submitted December 17, 2009; accepted June 8, 2010; posted ahead of print June 11, 2010. doi:10.1061/(ASCE)WW.1943-5460.0000064
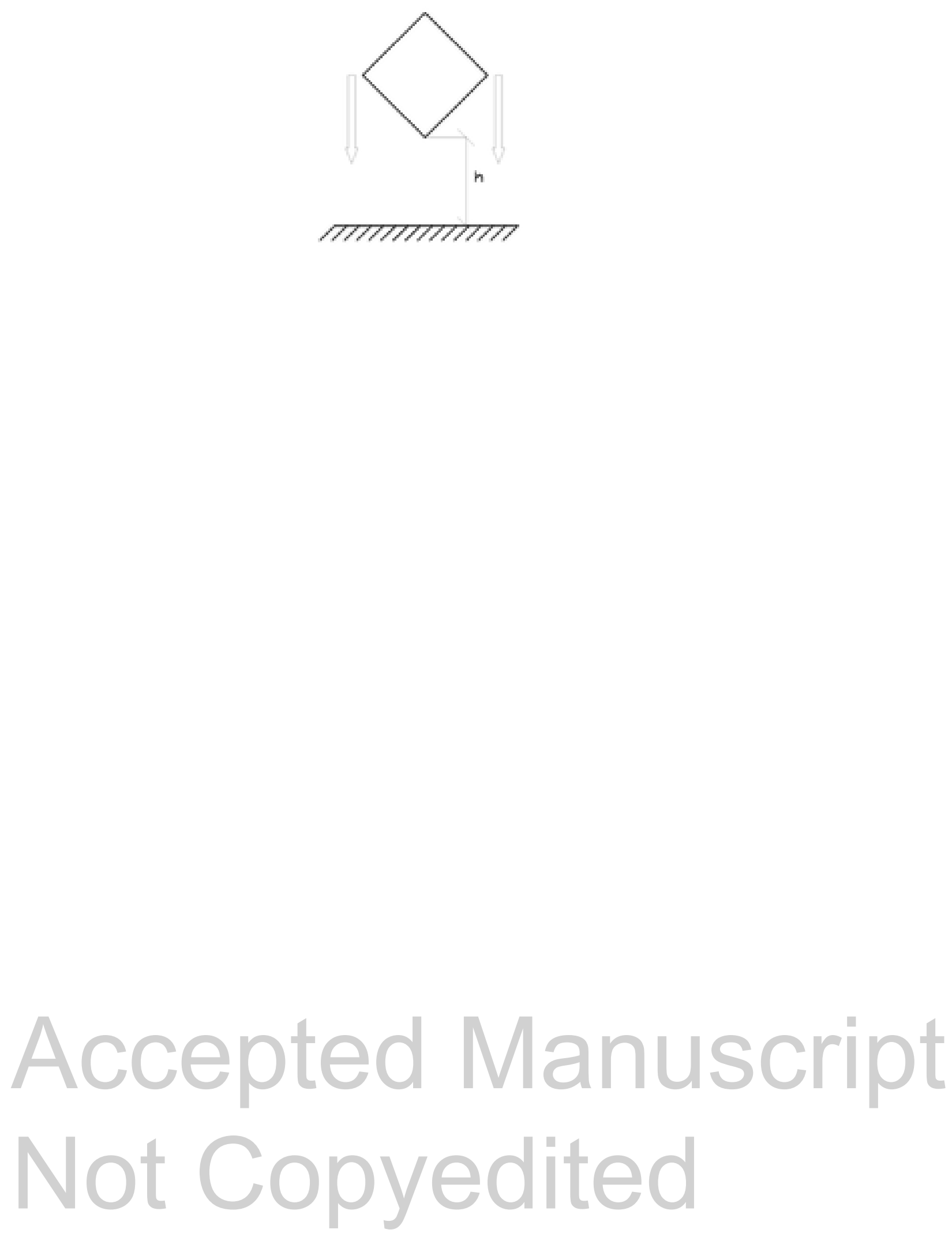

Copyright 2010 by the American Society of Civil Engineers 


\section{Figure $4 b$}

Journal of Waterway, Port, Coastal, and Ocean Engineering. Submitted December 17, 2009; accepted June 8, 2010; posted ahead of print June 11, 2010. doi:10.1061/(ASCE)WW.1943-5460.0000064
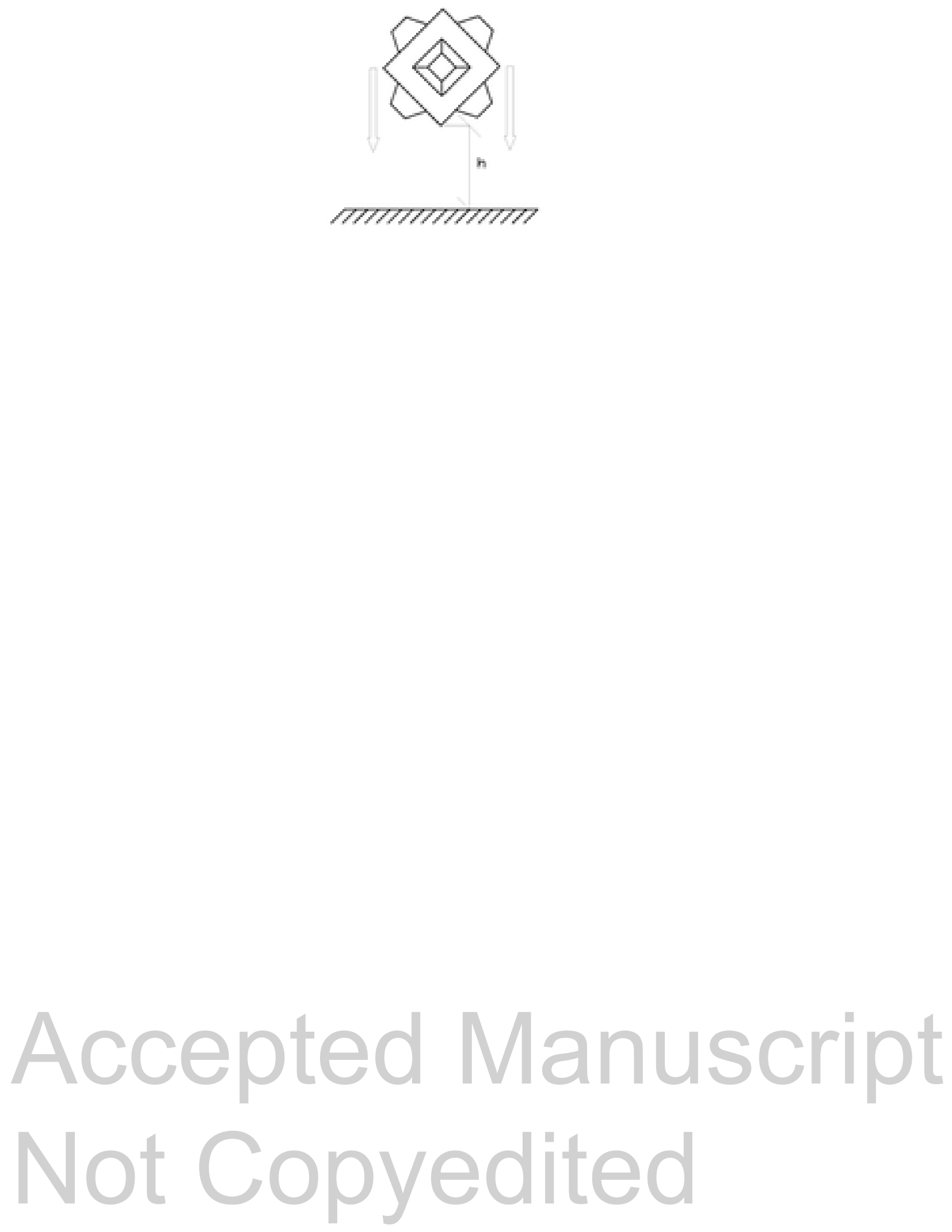

Copyright 2010 by the American Society of Civil Engineers 
Journal of Waterway, Port, Coastal, and Ocean Engineering. Submitted December 17, 2009; accepted June 8, 2010; posted ahead of print June 11, 2010. doi:10.1061/(ASCE)WW.1943-5460.0000064
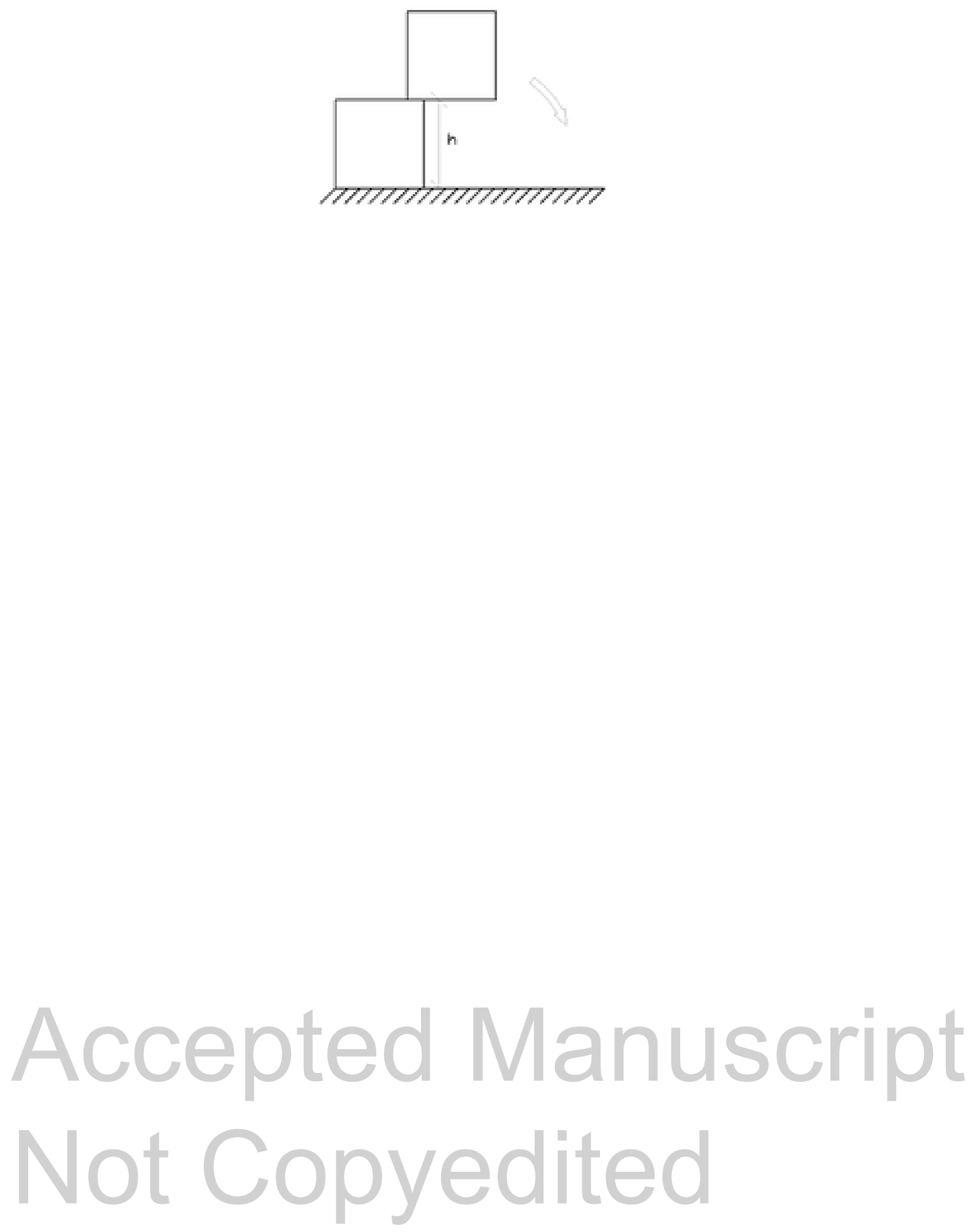

Copyright 2010 by the American Society of Civil Engineers 


\section{Figure 5b}

Journal of Waterway, Port, Coastal, and Ocean Engineering. Submitted December 17, 2009; accepted June 8, 2010; posted ahead of print June 11, 2010. doi:10.1061/(ASCE)WW.1943-5460.0000064
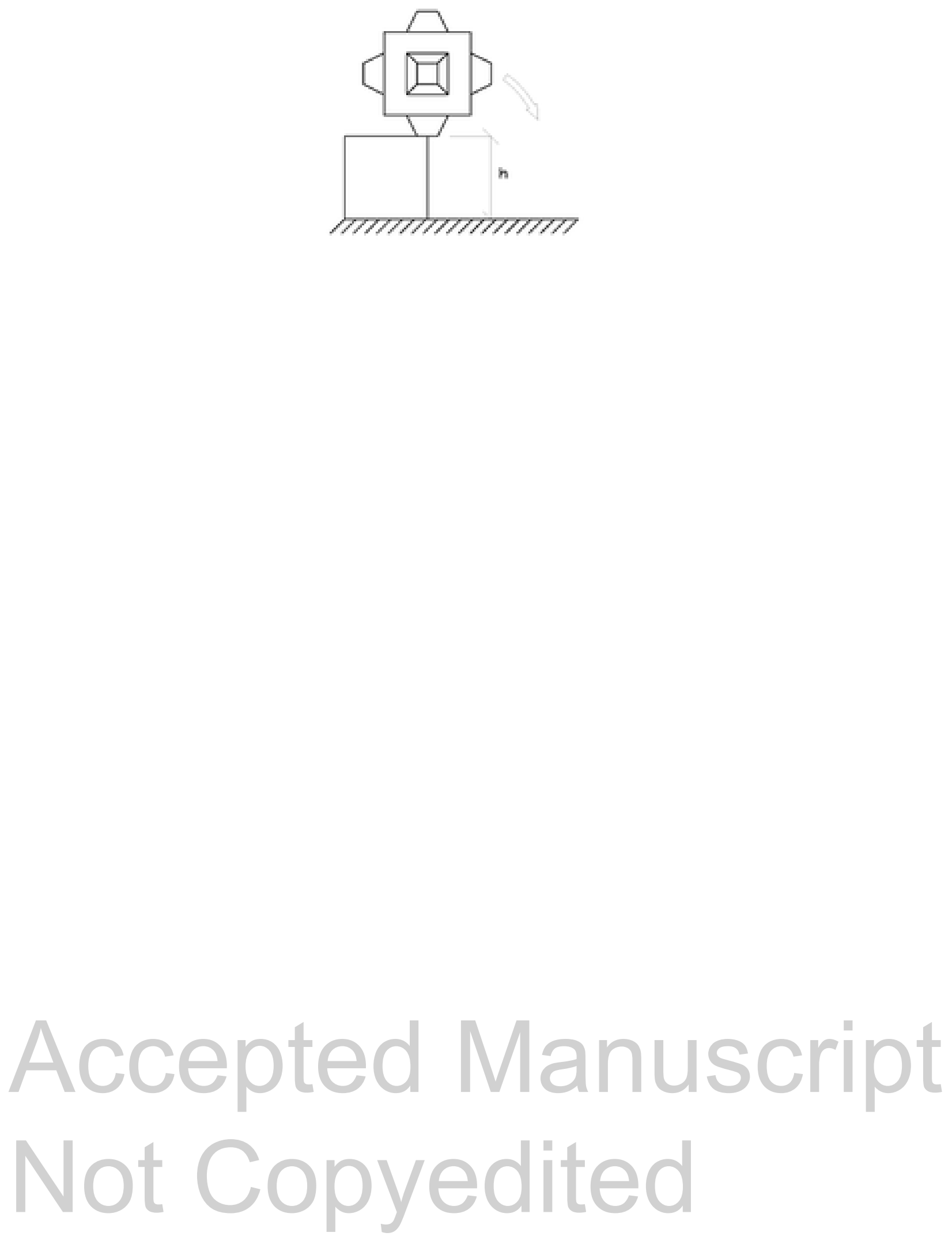
Figure 6

Journal of Waterway, Port, Coastal, and Ocean Engineering. Submitted December 17, 2009; accepted June 8, 2010; posted ahead of print June 11, 2010. doi:10.1061/(ASCE)WW.1943-5460.0000064
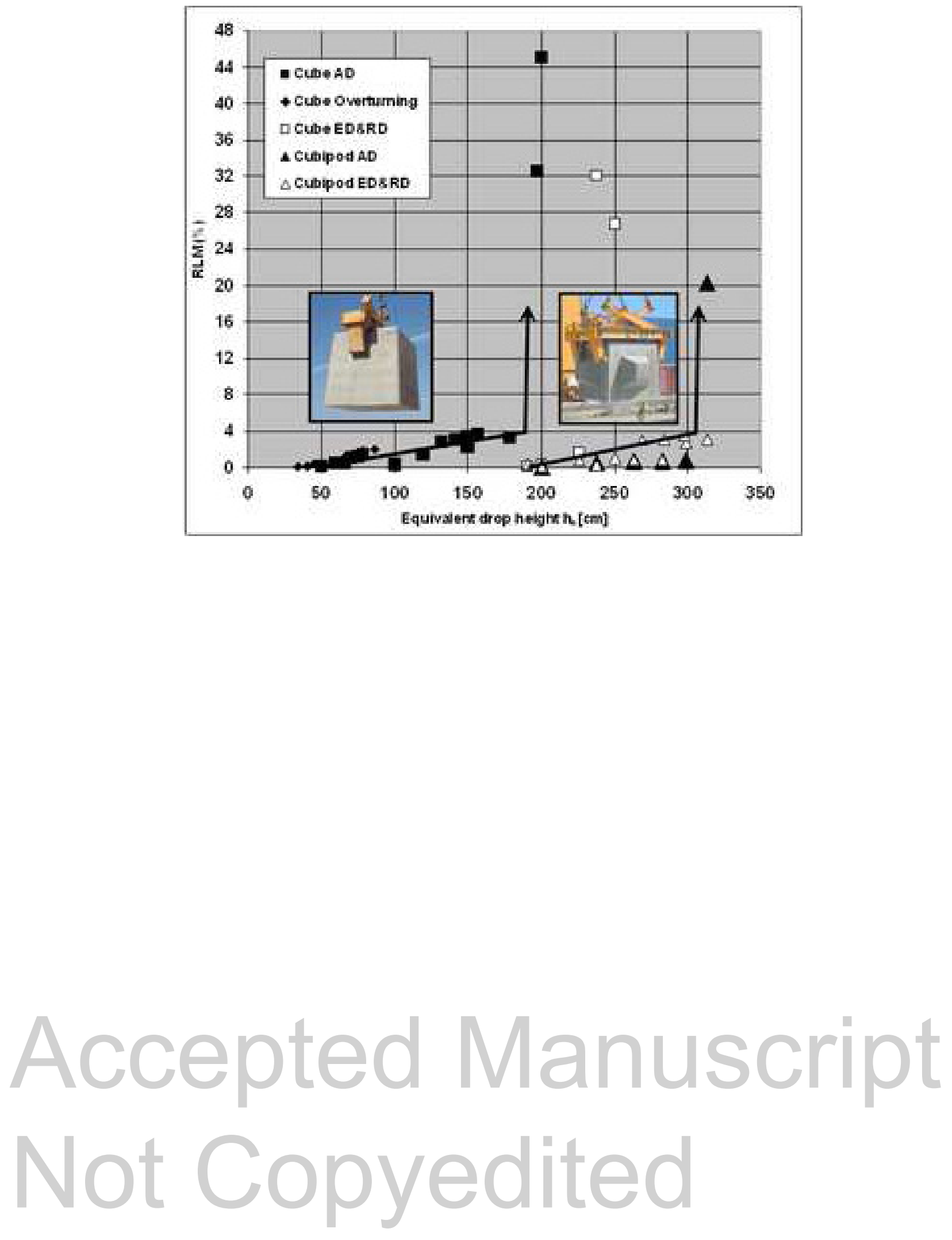
Figure 7

Journal of Waterway, Port, Coastal, and Ocean Engineering. Submitted December 17, 2009; accepted June 8, 2010; posted ahead of print June 11, 2010. doi:10.1061/(ASCE)WW.1943-5460.0000064
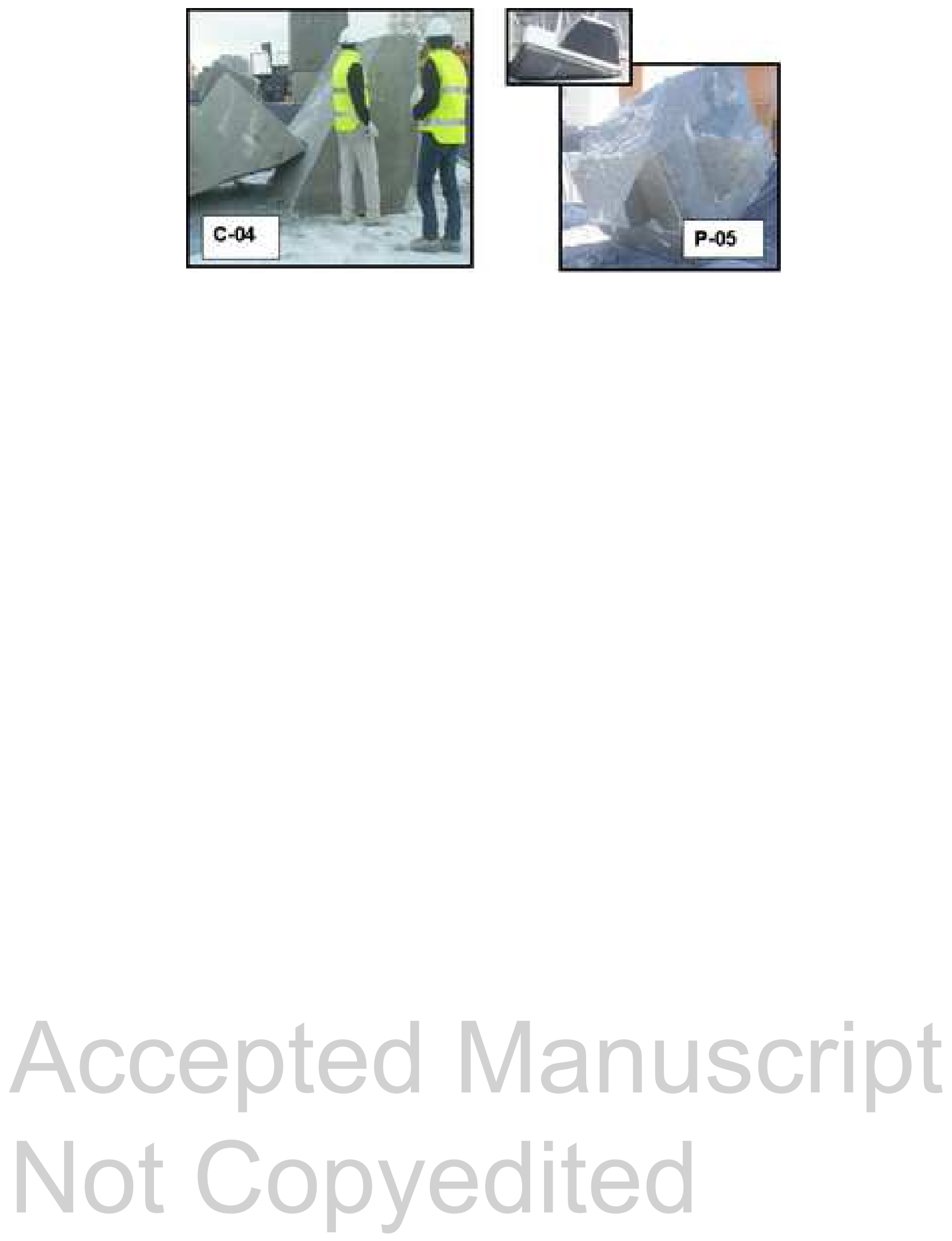
Journal of Waterway, Port, Coastal, and Ocean Engineering. Submitted December 17, 2009; accepted June 8, 2010; posted ahead of print June 11, 2010. doi:10.1061/(ASCE)WW.1943-5460.0000064
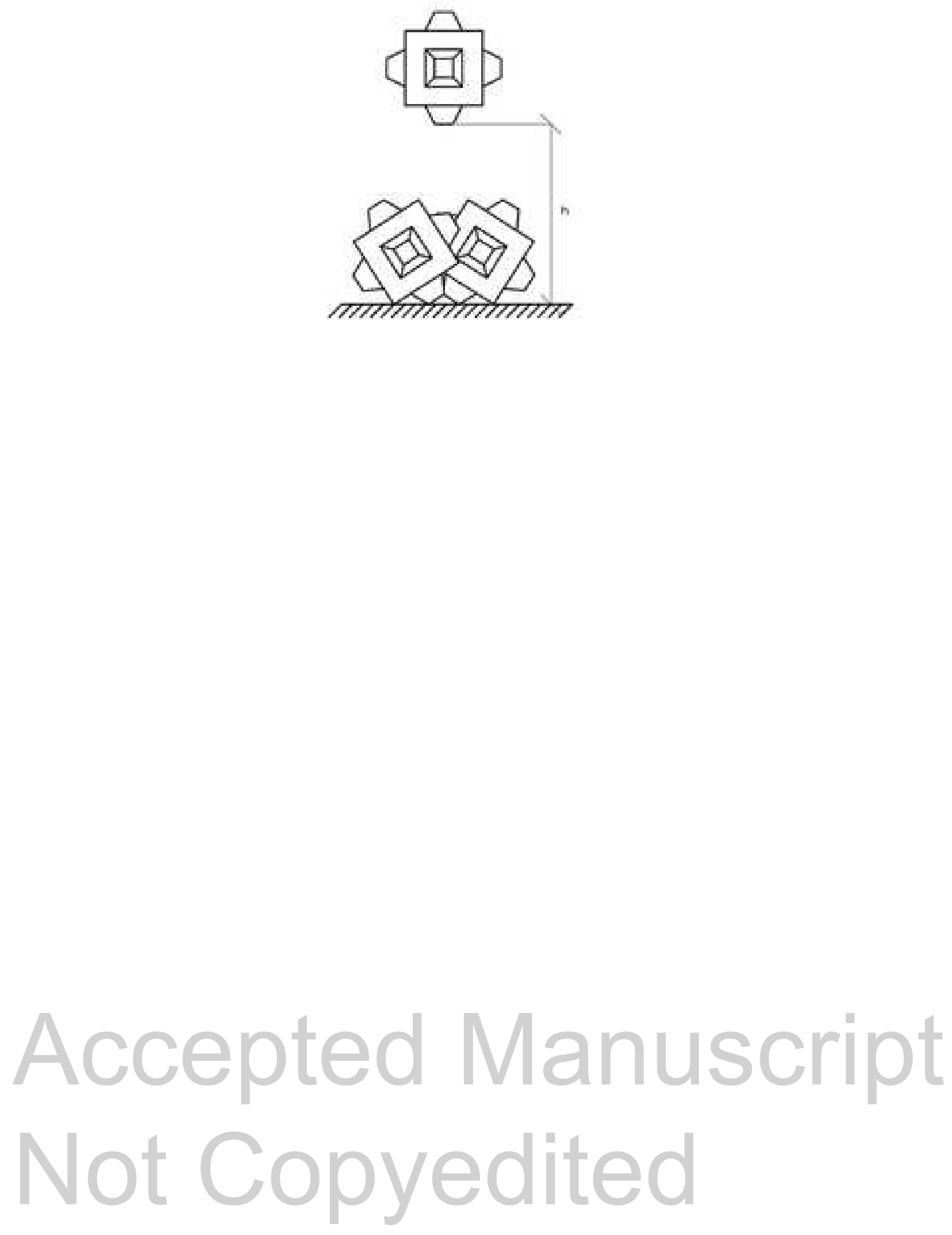

Copyright 2010 by the American Society of Civil Engineers 
Figure $8 b$

Journal of Waterway, Port, Coastal, and Ocean Engineering. Submitted December 17, 2009; accepted June 8, 2010; posted ahead of print June 11, 2010. doi:10.1061/(ASCE)WW.1943-5460.0000064
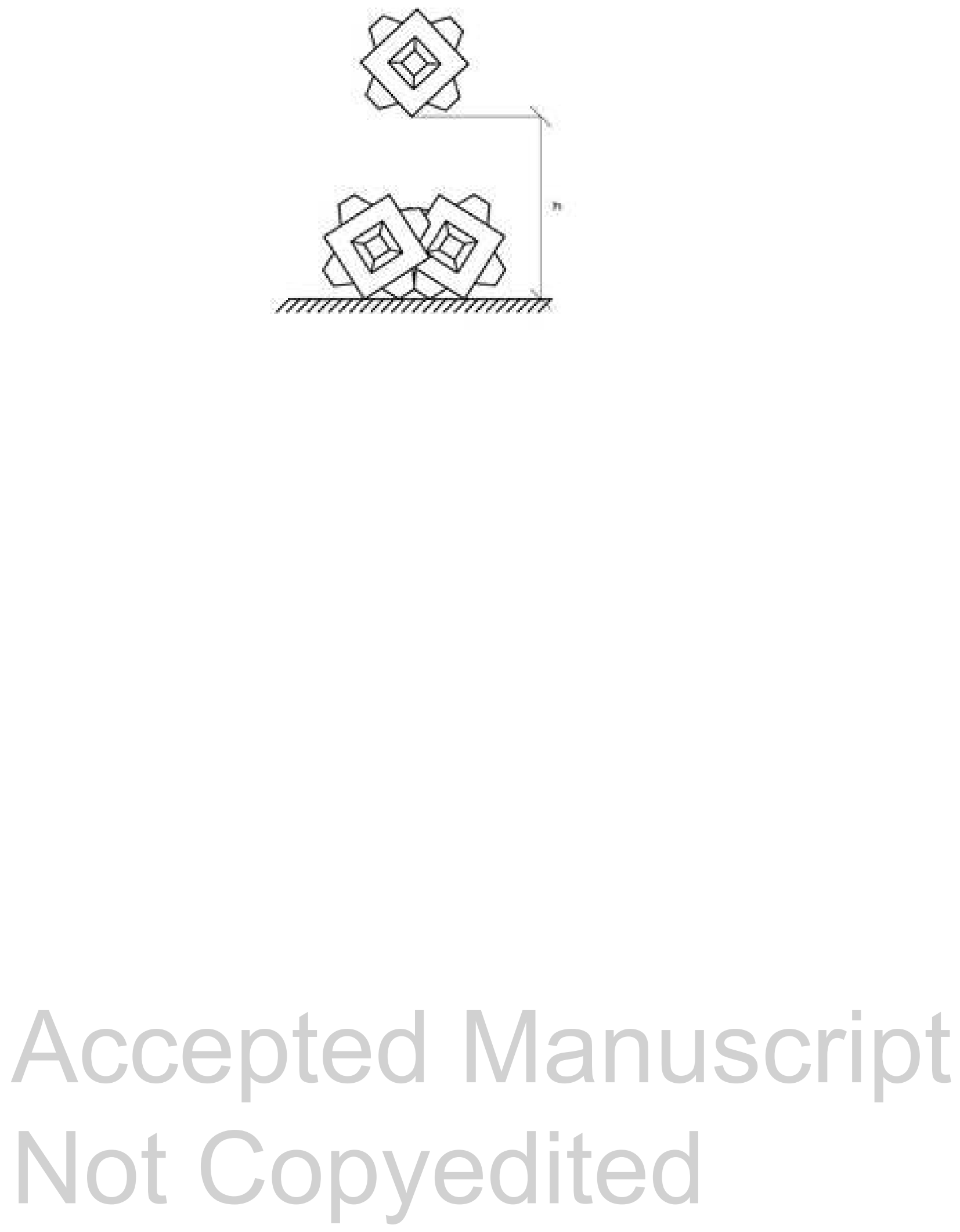

Copyright 2010 by the American Society of Civil Engineers 